\title{
Syntheses and transformations of alicyclic $\beta$-aminohydroxamic acids
}

\author{
PhD Thesis
}

\section{Beáta Fekete}

Supervisor:

Prof. Dr. Ferenc Fülöp

Dr. Márta Palkó

Institute of Pharmaceutical Chemistry

University of Szeged 


\section{CONTENTS}

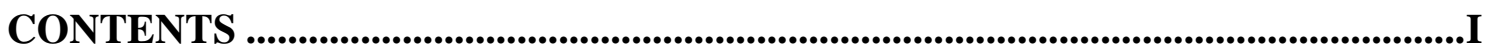

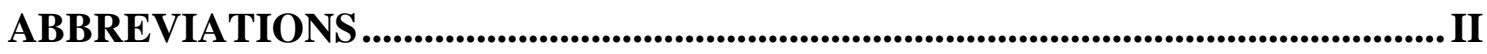

PUBLICATIONS ............................................................................................... III

1. INTRODUCTION AND AIMS ...........................................................1

2. LITERATURE BACKGROUND..............................................................

$2.1 \quad$ Structure and reactivity of hydroxamic acids ................................................. 3

2.2 Pharmacology of hydroxamic acids ........................................................... 4

2.2.1 Matrix metalloproteinase inhibitors …………………………………….... 4

2.2.2 Histondeacetylase inhibitors .................................................................... 5

2.2.3 Tumour necrosis factor-alpha converting enzyme inhibitors .............................. 6

2.2.4 Carbonic anhydrase inhibitors ....................................................................

2.2.5 Lypoxygenase and leukotriene $A_{4}$ hydrolase inhibitors .................................... 8

2.2.6 Antibacterial hydroxamic acids .................................................................. 8

2.3 Synthesis of hydroxamic acids by forming a hydroxamic acid functional group. 9

2.3.1 Syntheses from carboxylic acid derivatives ....................................................... 10

2.3.2 Enabling techniques for the synthesis of hydroxamic acids .............................. 14

2.4 Synthesis of aromatic and alicyclic $\beta$-amino hydroxamic acids......................... 16

2.5 Ring-closure reaction of anthranilic hydroxamic acids ...................................... 19

3. RESULTS AND DISCUSSION ................................................................... 21

3.1 Synthesis of new racemic alicyclic $\beta$-aminohydroxamic acids ……………….. 21

3.2 Synthesis of new enantiomer enriched alicyclic $\beta$-aminohydroxamic acids ...... 22

3.3 Domino reaction of diendo- and diexo-2-aminonorbornene hydroxamic acids

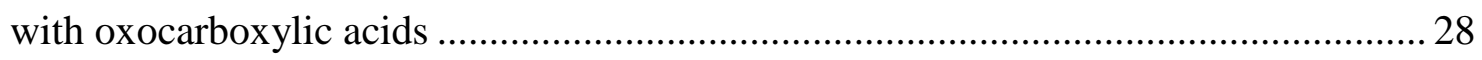

3.4 Retro Diels-Alder reactions of isoindolo[2,1-a]quinazolines and pyrrolo-

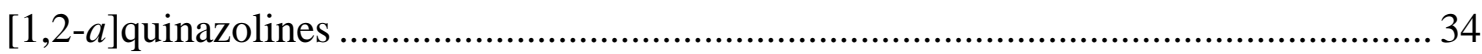

4. EXPERIMENTAL .................................................................................................39

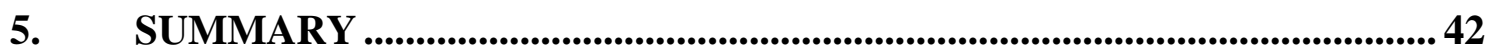

ACKNOWLEDGMENTS ................................................................................................ 45

TABLE OF THE SYNTHESIZED COMPOUNDS ..................................................... 46

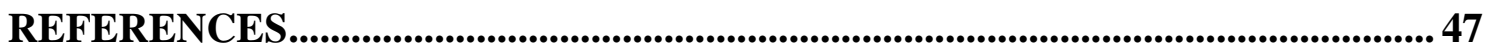

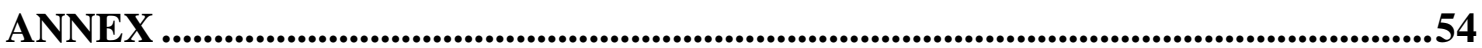




\section{ABBREVIATIONS}

$\begin{array}{ll}\text { COX } & \text { cyclooxygenase } \\ \text { DCB } & 1,2 \text {-dichlorobenzene } \\ \text { DBTA } & O, O \text {-dibenzoyltartaric acid } \\ \text { DIAD } & \text { diisopropyl azodicarboxylate } \\ \text { DMF } & \text { dimethylformamide } \\ \text { DPTTA } & O, O \text {-di- } p \text {-toluoyltartaric acid } \\ \text { HIV } & \text { human immunodeficiency virus } \\ \text { HPLC } & \text { high performance liquid chromatography } \\ \text { ECM } & \text { extracellular matrix } \\ \text { GC } & \text { gas chromatography } \\ \text { HDAC } & \text { hyston deacetylase } \\ \text { LOX } & \text { lipoxygenase } \\ \text { LTA } 4 & \text { leukotriene A } \\ \text { MMP } & \text { matrix metalloproteinase } \\ \text { NMP } & N \text {-methylmorpholine } \\ \text { NMR } & \text { nuclear magnetic resonance spectroscopy } \\ \text { PPh } & \text { triphenylphosphine } \\ p \text {-TSA } & p \text {-toluenesulfonic acid } \\ \text { RDA } & \text { retro Diels-Alder reaction } \\ \text { SAHA } & \text { suberoylanilidehydroxamic acid } \\ \text { TACE } & \text { tumor necrosis factor- } \alpha \text { converting enzyme } \\ \text { TFA } & \text { trifluoroacetic acid } \\ \text { TLC } & \text { thin-layer chromatography }\end{array}$




\section{PUBLICATIONS}

Papers related to the thesis

I. Beáta Fekete, Márta Palkó, István Mándity, Matti Haukka, Ferenc Fülöp:

A domino ring-closure followed by retro-Diels-Alder reaction for the preparation of pyrimido[2,1-a]isoindole enantiomers

European Journal of Organic Chemistry 2016, 21, 3519-3527.

II. Beáta Fekete, Márta Palkó, Matti Haukka, Ferenc Fülöp:

Synthesis of pyrrolo[1,2- $a$ ]pyrimidine enantiomers via domino ring-closure

followed by retro Diels-Alder protocol

Molecules 2017, 22, 1-13.

III. Gyula Lajkó, Tímea Orosz, Nóra Grecsó, Beáta Fekete, Márta Palkó, Ferenc Fülöp, Wolfgang Lindner, Antal Péter, István Ilisz:

High-performance liquid chromatographic enantioseparation of cyclic $\beta$ aminohydroxamic acids on zwitterionic chiral stationary phases based on Cinchona alkaloids

Analytica Chimica Acta 2016, 921, 84-94.

IV. Attila Bajtai, Beáta Fekete, Márta Palkó, Ferenc Fülöp, Wolfgang Lindner, Michal Kohout, István Ilisz, Antal Péter

A comparative study for the liquid chromatographic enantioseparation of cyclic $\beta$ amino acids and the related cyclic $\beta$-aminohydroxamic acids on Cinchona alkaloidbased zwitterionic chiral stationary phases

Journal of Separation Science 2018, 41, 1216-1223. 


\section{Conference lectures}

\section{Fekete Beáta:}

Norbornénvázas aminohidroxámsavak szintézise és gyürüzárási reakcióinak vizsgálata

„A Szegedi Ifjú Szerves Kémikusok Támogatásáért” Alapitvány tudományos elöadóülése,

Szeged, 2014. május 7.

\section{Fekete Beáta:}

Norbornénvázas aminohidroxámsavak domino gyürüzárási reakcióinak vizsgálata Heterociklusos és elemorganikus kémiai munkabizottság ülése, Balatonszemes, 2015. május 27-29.

\section{Fekete Beáta:}

Pirimido[2,1-a]izoindolok és pirrolo[1,2-a]pirimidinek előállítása norbornénvázas $\beta$-aminohidroxámsavak domino és RDA reakcióival Gyógyszerkémiai és Gyógyszertechnológiai Szimpózium 2016. Herceghalom, 2016. szeptember 15-16. 


\section{INTRODUCTION AND AIMS}

The first hydroxamic acid—oxalohydroxamic acid—was discovered almost 150 years ago by Lossen, ${ }^{[1]}$ but this class of compounds raised further interest just in the beginning of the 1980s due to their valuable biological and pharmacological properties (Figure 1).

The hydroxamic acid moiety is found in several natural compounds produced by plants, ${ }^{[2]}$ bacteria $^{[3]}$ and fungi ${ }^{[4]}$ to help their iron uptake via chelation. Desferrioxamine B, a hydroxamate-type natural siderophore (synthetized by Streptomyces pilosus) is well-known in the treatment of transfusion-induced iron overload ${ }^{[5]}$ (Figure 1).

Synthetic hydroxamates can be useful as well in many pathophysiological conditions. For example, ciclopirox ${ }^{[6]}$ is found to be effective in topical fungal infections, while vorinostat $^{[7]}$ (SAHA, suberoylanilidehydroxamic acid) has been approved by the Food and Drug Administration in the USA as the treatment of cutaneous T-cell lymphoma (Figure $1)$.

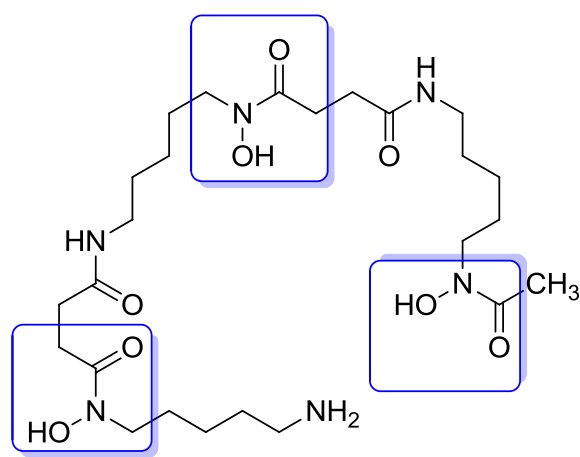

Desferrioxamine-B

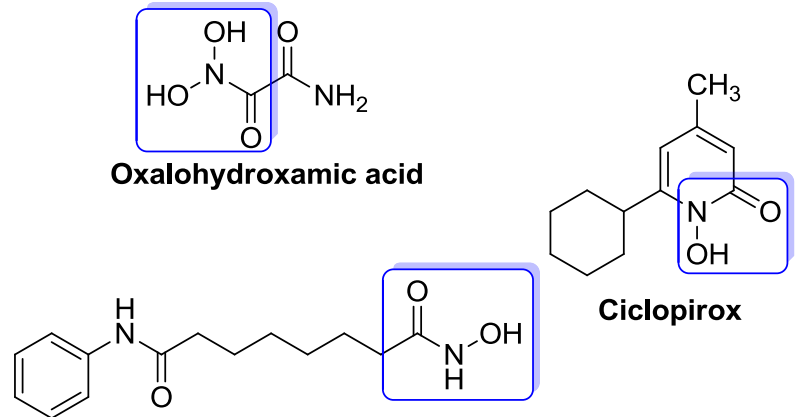

Vorinostat (SAHA)

Figure 1

There are several applications of hydroxamic acids in organic and analytical chemistry. For example, they can be used in the spectrophotometric determination of vanadium ions ${ }^{[8]}$ or in asymmetric synthesis as chiral ligands. ${ }^{[9]}$

In view of the growing importance of hydroxamic acid derivatives, the major aim of my $\mathrm{PhD}$ work was to develop a simple route for the preparation of new alicyclic $\beta$ aminohydroxamic acids. We achieved the syntheses of new racemic and enantiomeric form of cis- and trans-2-aminocyclohexane-hydroxamic acids, cis- and trans-2-aminocyclohex4-ene-hydroxamic acids [IV], diendo- and diexo-3-aminobicyclo[2.2.1]hept-5-ene-2hydroxamic acids [I,II] and diendo- and diexo-3-aminobicyclo[2.2.1]heptane-2- 
hydroxamic acids [III] starting from the appropriate esters. The structures of the synthesized alicyclic $\beta$-aminohydroxamic acids are shown in Figure 2.<smiles>NC1CCCCC1C(=O)NO</smiles><smiles>N[C@@H]1CCCCC1C(=O)NO</smiles><smiles>NC1CC=CCC1C(=O)NO</smiles><smiles>N[C@@H]1CC=CCC1C(=O)NO</smiles><smiles>NC(=O)C1C2C=CC(C2)C1NO</smiles><smiles>NC1C2C=CC(C2)C1C(=O)O</smiles><smiles>NC(=O)C1C2CCC(C2)C1NO</smiles><smiles>NC1C2CCC(C2)C1C(=O)O</smiles>

Figure 2

Our further aim was to study the diastereoselectivity of the domino ring-closure reaction of diendo- and diexo-2-aminonorbornenehydroxamic acids with oxocarboxylic acids, to examine the RDA reaction of the formed isoindolo[2,1-a]quinazolinones, and to extend this methodology to obtain novel racemic and enantiomeric pyrrolo[1,2-a]pyrimidine and pyrimido[2,1-a] isoindole derivatives [I,II] (Scheme 1).<smiles>CCOC(=O)C1C2C=CC(C2)C1N</smiles>

diendo, diexo<smiles>[R]N1C(=O)C=CN2C(=O)c3ccccc3C12[R]</smiles>

Scheme 1

The publications on which the thesis is based are referred to in square brackets, while other references are given as superscripts. 


\section{LITERATURE BACKGROUND}

Hydroxamic acids constitute a major class of organic compounds. They have a wide variety of pharmacological actions targeting cancers, cardiovascular diseases, HIV, Alzheimer's disease, malaria, and allergic diseases. Hydroxamic acids are conventionally synthesized from carboxylic acids and their derivatives (esters, acid chlorides) with hydroxylamine hydrochloride under basic conditions in batch reaction. However, some other compounds, namely, aldehyde, amine, amide and alcohol can also be converted to hydroxamate with ease. The solid-phase synthesis techniques are also gaining importance for the synthesis of hydroxamic acids and these pathways have opened a wide arena for the synthesis of diverse and complex hydroxamic acids.

The literature part of my thesis focuses on the structure and reactivity of hydroxamic acids (2.1), their pharmacology (2.2), conventional and non-conventional synthesis of hydroxamic acids to form the $\mathrm{CONHOH}$ group (2.3). The aim was to present the most varied synthetic techniques for the formation of the hydroxamic acid functional group. In the second part of the literature section (2.4 and 2.5) the syntheses of alicyclic and aromatic $\beta$-amino hydroxamic acids and the ring-closure reactions of anthranilic hydroxamic acid are presented.

\subsection{Structure and reactivity of hydroxamic acids}

Hydroxamic acids are weak acids with a $\mathrm{pKa} \approx 9$ (in aqueous solution); however their acidity strongly depends on the electronic properties of the substituents. They can act as both $N$ - and $O$-acids. The type of deprotonation appears to depend on the mode of substitution, the method used (solid, liquid or gas phase), and the nature of the solvent. ${ }^{[10]}$ Their general formula is $\mathrm{R}-\mathrm{CO}-\mathrm{NH}-\mathrm{OH}$ where $\mathrm{R}$ is $\mathrm{H}$ or organic group. The planar structure and the bond lengths of the moiety indicate partial carbon-nitrogen double bond character similar to that found in amides. ${ }^{[11]}$ The hindered rotation about the $\mathrm{C}-\mathrm{N}$ bond results in $Z-E$ isomerism. The percentage of $E$ configuration in the $Z / E$ equilibrium decreases with the increase of the size of the substituent at nitrogen. ${ }^{[11]}$ Hydroxamic acids exhibit keto-enol tautomerism and have several resonance contributing structures (Figure 3). ${ }^{[12]}$ Keto forms are predominant under acidic conditions, while enol (iminol) forms are more stable in alkaline media. ${ }^{[13]}$ Hydroxamic acids can exist in Z-keto, $E$-keto, Z-enol or $E$-enol forms (Figure 3). From pharmacological aspects, it is important to note that hydroxamic acids have metal- 
chelating property and hydrogen bond formation ability, which are essential in the interaction with enzymes. ${ }^{[14]}$ They can act as both monodentate and bidentate ligands through their deprotonated hydroxamate moiety and carbonyl oxygen. $\beta$ Aminohydroxamic acids form six-membered $N, N$-coordinated ring or five-membered $O, O$-coordinated ring with $\mathrm{Cu}(\mathrm{II})$ as shown in the case of $\beta$-alaninehydroxamic acid in Figure 3. ${ }^{[15]}$

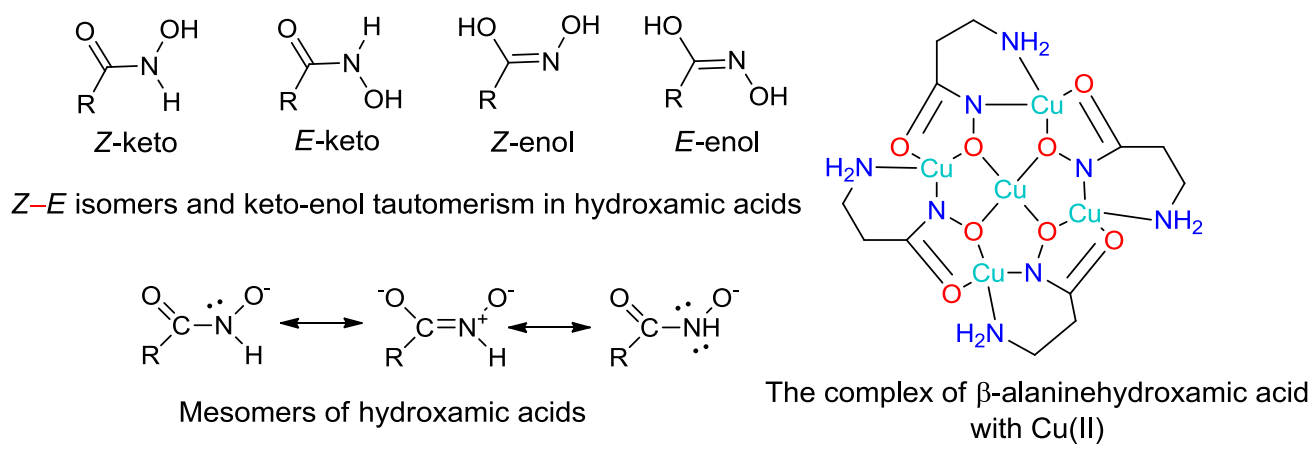

Figure 3

Because of the lone electron pairs of nitrogen and oxygen and the hydrogens of the amide and hydroxy group, hydroxamic acids have several possibilities to accept and donate hydrogen to form hydrogen bonds. They are able to form intra- and intermolecular bonds as well. This phenomenon is of key importance in the interaction with biopolymers and in this way in drug design.

\subsection{Pharmacology of hydroxamic acids}

Hydroxamic acids strongly chelate metal ions in the catalytically active site of several metalloenzymes. ${ }^{[12]}$ Furthermore, they are able to release nitric oxide in living systems, which has physiological and pathophysiological importance in the cardiovasculare system. ${ }^{[16]}$ In this part of the thesis, some pharmacologically reliable metalloenzymes as targets of hydroxamate-type drug candidates will be introduced.

\subsubsection{Matrix metalloproteinase inhibitors}

Matrix metalloproteinases (MMPs) are zinc- and calcium-containing proteolytic enzymes (endopeptidases), which are essential in degrading and remodeling extracellular matrices (ECMs). ECMs have crucial role in cell migration, proliferation, growth and development, while over-expression is associated with remodelling of heart, arthritis, periodontal disease, multiple sclerosis and cancers (metastasis and angiogenesis). ${ }^{[17]}$ Marimastat, prinomastat and other selective and non-selective hydroxamate-type MMP inhibitors are in advanced clinical trials in the therapy of lung cancers ${ }^{[18]}$ (Figure 4). 


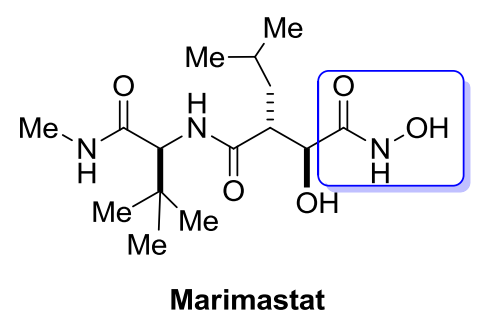

Marimastat

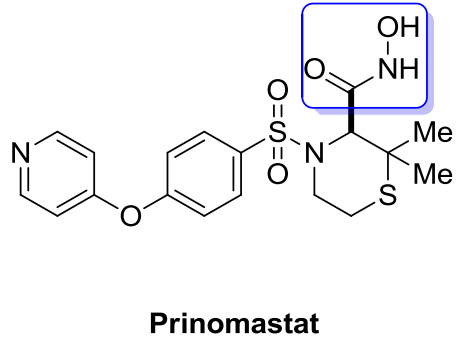

Prinomastat

Figure 4

\subsubsection{Histondeacetylase inhibitors}

Further promising agents in cancer therapy are inhibitors of zinc-dependent class I and II histondeacetylases. They take part in cell-cycle progression, differentiation and apoptosis of malignant cells. ${ }^{[19]}$ There can be found various hydroxamic acid derivatives (HDACIs) in the literature. ${ }^{[20]}$ Suberoylanilide hydroxamic acid (SAHA, vorinostat, Zolinza ${ }^{\circledR}$, see in Figure 1) is one of the most well-known, which is already used in cancer therapy for the treatment of cutaneous T-cell lymphoma. ${ }^{[21]}$ Panobinostat and belinostat are more potent inhibitors of HDAC I and II than vorinostat $\left(\mathrm{IC}_{50}\right.$ values in $\mathrm{nM}$ concentration against HDAC I and HDAC II = vorinostat: 75.5, 362; panobinostat: 2.5, 13.2; belinostat: 17.6, 33.3). ${ }^{[22]}$ Amamistatins, natural products isolated from Nocardia asteroides, were found to be effective against MCE-7 breast and MKN45 stomach cancer cell lines. Amamistan A and $\mathrm{B}$ also show activity against mouse lymphatic leukemia cells P388 ( IC $_{50} 15$ and 16 ng/mL). ${ }^{[23]}$ Promising results have been found with piperazine hydroxamates, ${ }^{[24]} 5$ membered cyclic hydroxamic acids ${ }^{[20]}$ and other derivatives ${ }^{[19 b]}$ as well ${ }^{[25]}$ (Figure 5).

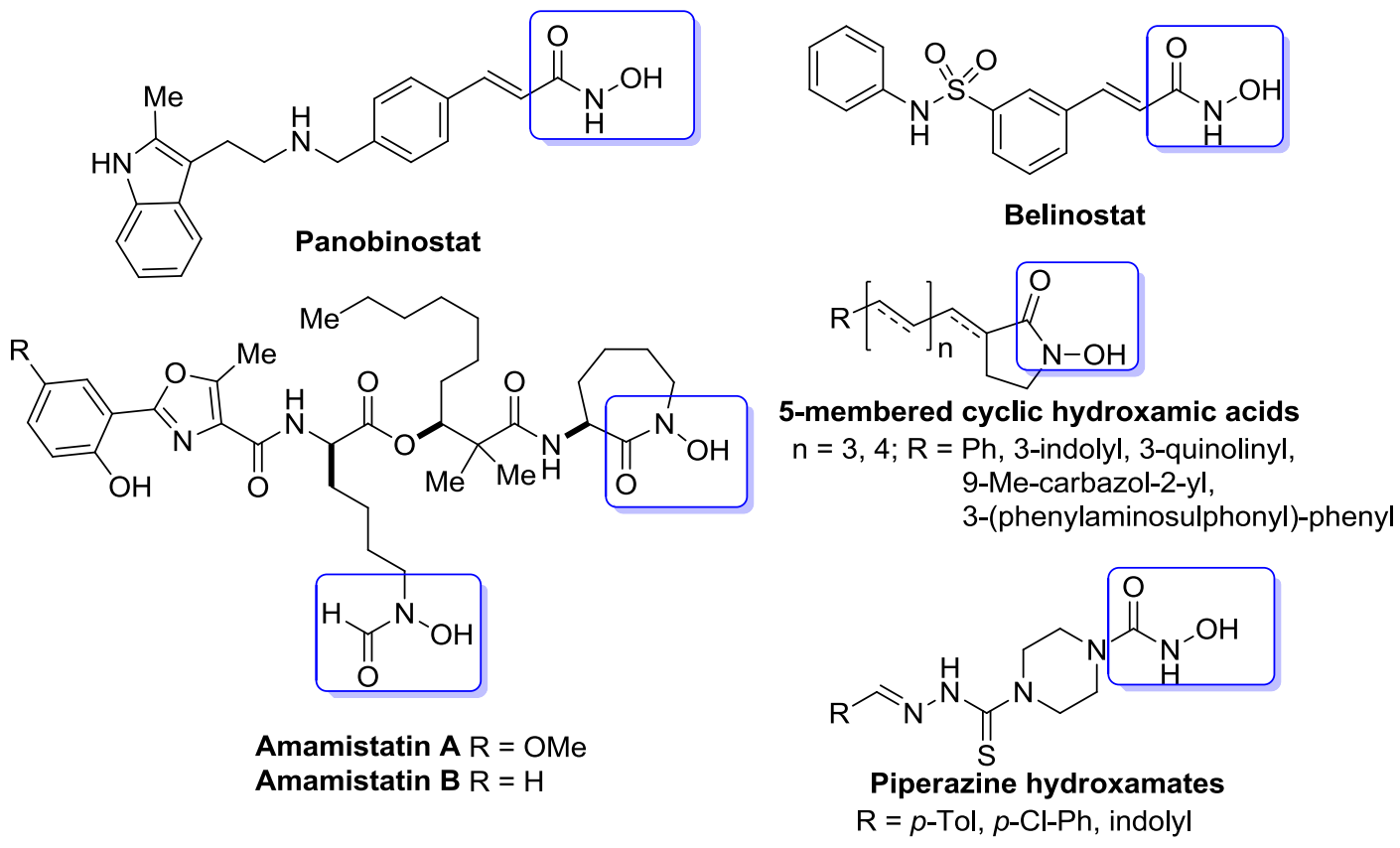

Figure 5 


\subsubsection{Tumour necrosis factor-alpha converting enzyme inhibitors}

Tumour necrosis factor-alpha converting enzyme (TACE) is a zinc-containing metalloproteinase, which cleaves pro-TNF- $\alpha$ (233 amino acid protein) at Ala76 and Val77 and releases immunomodulatory cytokine TNF- $\alpha .{ }^{[26]}$ Over-expression of TNF- $\alpha$ causes numerous pathological conditions, such as rheumatoid arthritis, multiple myeloma, atherosclerosis, stroke and Crohn's disease. ${ }^{[27]}$ There are further studies that highlight the role of TNF- $\alpha$ in neurodegenerative disorders like Alzheimer or Parkinson's disease, in stroke and in viral or bacterial infection. ${ }^{[28]}$ Selective TACEI molecules designed recently have attracted significant interest. Barlaam et al. synthesized succinate-based hydroxamic acids and examined the inhibition of TACE in whole blood assay. ${ }^{[29]}$ Macrocyclic hydroxamates were designed by Xue and his co-workers and potent molecules were prepared with $\mathrm{IC}_{50}$ values of $\leq 0.2 \mu \mathrm{M} \cdot{ }^{[30]} \gamma$-Lactam hydroxamic acids were synthesized by Duan and his co-workers and discovered orally bioavailable compounds. ${ }^{[31]}$ Cherney et al. converted non-selective sulphonamide MMP inhibitors into selective TACE inhibitor benzothiadiazepine hydroxamates. ${ }^{[32]}$ Novel $\beta$-amino heterocyclic hydroxamic acid scaffolds containing benzo $[d]$ imidazol TACEI molecules were designed by Ott and his coworkers and tested on whole blood assay. ${ }^{[33]}$ The most potent TACE inhibitors are represented in Figure 6. 


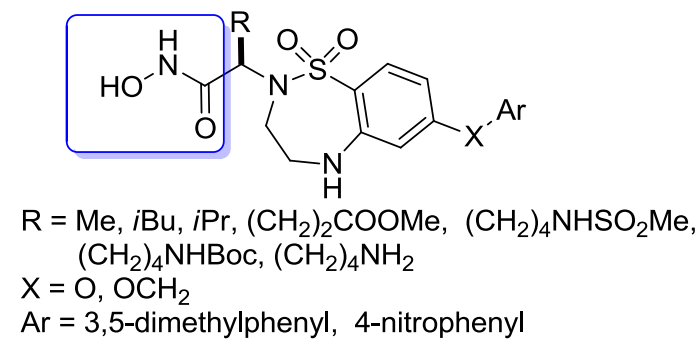

Benzothiadiazepine hydroxamic acids

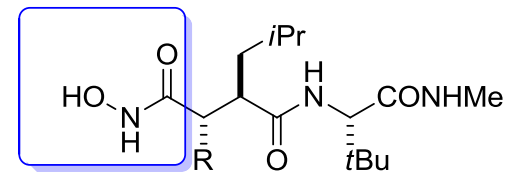

$\mathrm{R}=3,5-\mathrm{Cl}_{2} \mathrm{C}_{6} \mathrm{H}_{3} \mathrm{~S}$, (8-quinoline) $\mathrm{CH}_{2} \mathrm{~S}$,

$(E)-\mathrm{PhCH}=\mathrm{CHSO}{ }_{2} \mathrm{NH}$, quinoline-8- $\mathrm{CH}_{2} \mathrm{NH}$, naphthalene-1- $\mathrm{CH}_{2} \mathrm{O}, 2-(\mathrm{Me})$ benzothiazole

Succinate based hydroxamic acids<smiles>[X]CC(NC(=O)c1ccc(Cn2cnc3ccccc32)cc1)C1CC2CCCC1C2</smiles><smiles>[R]C(=O)C1CCCCNC(=O)OCCCC(C(=O)NO)[C@H](CC(C)C)C(=O)NCCCC1</smiles>

$\mathrm{R}=\mathrm{NH}[2-(6-$ methoxyndole-3-yl)ethyl], $\mathrm{NH}$ (2-hydroxy-2-phenylethyl), Gly(morpholine-4-yl),

Gly(4-phenylpiperazine-1-yl), Gly[4-(2-pyridinyl)piperazin-1-yl] Macrocyclic hydroxamic acids<smiles>[R]c1ccc([C@]2(C)CCN(C(C)(C)C(=O)NO)C2=O)cc1</smiles>

$\mathrm{R}=\mathrm{OBn}, \mathrm{Ph}, 2-\mathrm{NO}_{2}-\mathrm{BnO}, 3-\mathrm{NO}_{2}-\mathrm{BnO}$, 4- $\mathrm{NO}_{2}-\mathrm{OBn}, 3,5-\mathrm{di}-\mathrm{MeBnO}$, 3,5-di-MeO-BnO, 3,5-bis- $\mathrm{CF}_{3} \mathrm{BnO}$ $\gamma$-lactam hydroxamic acids<smiles>[R]c1nc2ccccc2n1Cc1ccc(C(=O)NC2CCCCC3(CCCCC3)C2)cc1</smiles>

$\mathrm{R}=i \mathrm{Pr}, \mathrm{CF}_{3} \mathrm{X}=\mathrm{CH}_{2}, \mathrm{CH}_{2} \mathrm{O}$

Benzo[d]imidazole hydroxamic acids

Figure 6

\subsubsection{Carbonic anhydrase inhibitors}

Carbonic anhydrases (CA) are zinc-containing enzymes, which catalyse the reversible hydration of carbon dioxide to bicarbonate ion. This process plays role in secreting acid in stomach, transforming pancreatic juice to alkaline, saliva to neutral and influence the water content of kidneys and eyes. Malfunction of carbonic anhydrases is associated with glaucoma, obesity, cancers, and epilepsy. Hydroxamic acid and sulfonamide hydroxamate CA inhibitors are ideal lead molecules for the invention of new diuretics, antiglaucoma agents and antiepileptics ${ }^{[34]}$ (Figure 7).

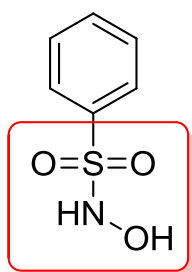<smiles>[X]C(C(=O)NO)N([X])S([R])(=O)=O</smiles>

Sulfonamide hydroxamic acids

$$
\begin{aligned}
& \mathrm{R}=\mathrm{H}, \mathrm{Me}, i \mathrm{Pr}, i \mathrm{Bu} \\
& \mathrm{R}^{1}=n-\mathrm{C}_{4} \mathrm{~F}_{9}, \mathrm{C}_{6} \mathrm{~F}_{5}, 4-\mathrm{MeO}-\mathrm{C}_{6} \mathrm{H}_{4} \\
& \mathrm{X}=\mathrm{H}, \mathrm{C}_{6} \mathrm{H}_{5} \mathrm{CH}_{2}, 2-\mathrm{NO}_{2}-\mathrm{C}_{6} \mathrm{H}_{4} \mathrm{CH}_{2}
\end{aligned}
$$

Figure 7 


\subsubsection{Lypoxygenase and leukotriene $A_{4}$ hydrolase inhibitors}

Eicosanoids including prostaglandins (PGs) and leukotriens (LTs) play key roles in the process of inflammation and their malfunction is related to several disorders like rheumatoid arthritis and osteoarthritis, asthma and psoriasis. PGs and LTs are synthetized from arachidonic acid (AA) via the metalloenzymes cyclooxygenase (COX) and lipoxygenase (LOX). ${ }^{[35]}$ LOX, COX and $\mathrm{LTA}_{4}$ hydrolase inhibitor hydroxamates are able to act as anti-inflammatory and anti-asthmatic agents. Linoleyl hydroxamic acid, studied as lipoxygenase inhibitor by Butovich and Lukyanova, was found to be effective against 15and 12-LOX. ${ }^{[36]}$ Tepoxalin has been approved for the treatment of osteoarthritis in dogs. ${ }^{[37]}$ Wong et al. synthesized $\beta$-aminohydroxamic acid derivatives, which are able to act as selective LTA $_{4}$ hydrolase inhibitors in vitro ${ }^{[38]}$ (Figure 8).
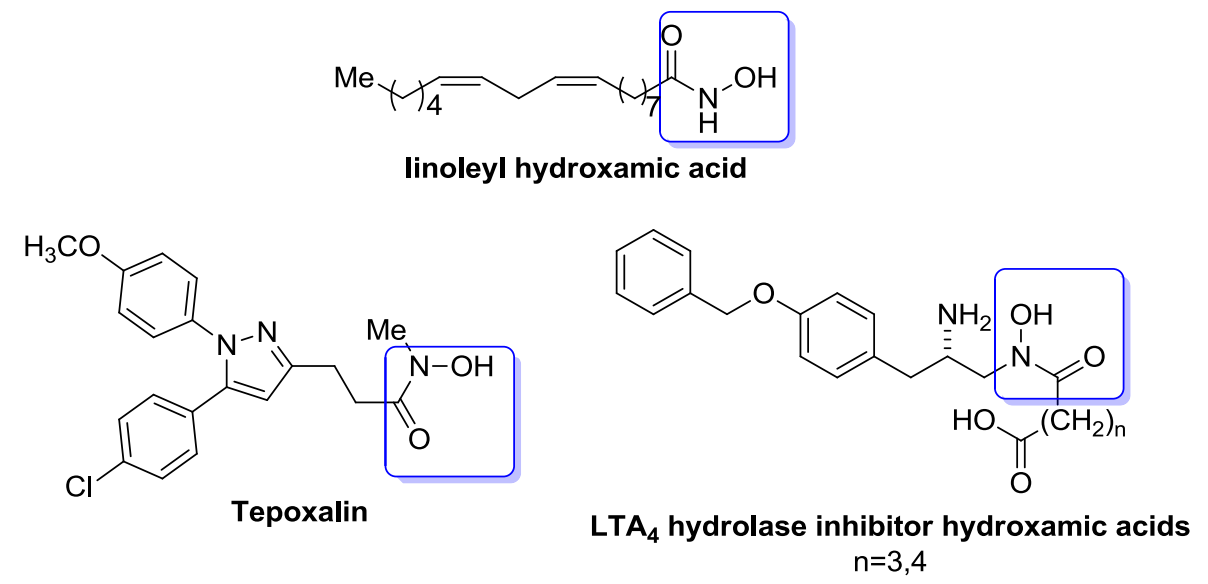

Figure 8

\subsubsection{Antibacterial hydroxamic acids}

There can be found several naturally occurring and synthetic hydroxamic acids with antimicrobial effect. ${ }^{[39]}$ They act via chelation of iron (which is essential for bacterial growth) or through selective enzymes inhibition. ${ }^{[40]}$

\subsubsection{Urease inhibitors}

Urease is a nickel-containing enzyme produced by several species including Helicobacter pylori (H.p.), which induces the hydrolysis of urea to ammonia and carbon dioxide. H.p. infections are related to gastritis, peptic ulcers and gastric carcinoma. Consequently, ureases have been intensively studied drug targets. ${ }^{[41]}$ Morikawa et al. tested a variety of hydroxamic acids (aliphatic, aromatic, amino acid and dipeptide derivatives as well) against H.p. urease and found aliphatic hydroxamic acids the most potent ones. ${ }^{[42]}$ Zhu $e t$ $a l$. invented $\beta$-hydroxy- $\beta$-phenylpropionylhydroxamic acids as candidates to develop new 
antiulcer agents. ${ }^{[43]}$ A series of phenyl- and diarylhydroxamic acids were synthesized by Muri and her co-workers as promising urease inhibitors ${ }^{[44]}$ (Figure 9).

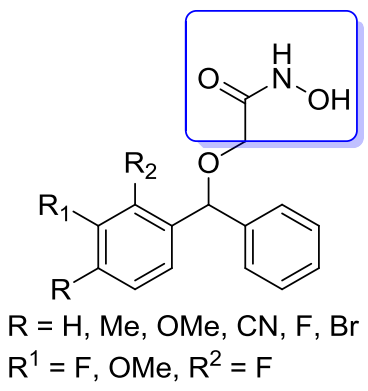

Diaryl and phenyl hydroxamic acids

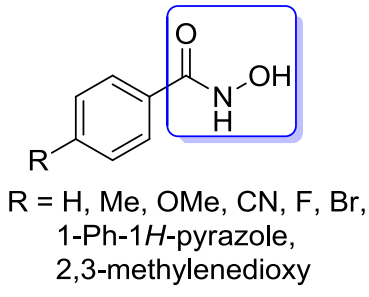

Figure 9

\subsubsection{Peptide deformylase inhibitors}

Peptide deformylase (PDF) is an enzyme, which removes the formyl group from the $\mathrm{N}$ terminal methionine of nascent polypeptides. This enzyme is ideal target for inventing new antibiotics, because it is essential for eubacteria and is not required for the protein synthesis in eukaryotes. ${ }^{[45]}$ Hubschwerlen et al. described the synthesis of $\beta$-sulfonyl- and $\beta$-sulfinyl-hydroxamic acids. The new compounds were tested against PDF of various bacterium species (E. coli, S. pneumonia, H. influenza, C. pneumonia, etc.) and found that $\beta$-sulfinylhydroxamic acids were more active than the corresponding $\beta$-sulfonyl derivatives. ${ }^{[46]}$ Molteni and her co-workers designed a series of benzothiazinone hydroxamic acids against K. pneumonia, S. aureus and E. coli ${ }^{[47]}$ (Figure 10).

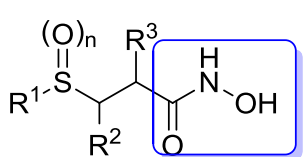

$\mathrm{R}^{1}=\mathrm{C}_{6} \mathrm{H}_{5}, n-\mathrm{Hex}, c-\mathrm{Hex}, \mathrm{Bn}, 4-\mathrm{MeO}-\mathrm{Ph}, 4-\mathrm{Br}-\mathrm{C}_{6} \mathrm{H}_{5}, 2-$ naphthyl

$\mathrm{R}^{2}=\mathrm{Me}, \mathrm{Et}, \mathrm{Pr}, \mathrm{Bu}, \mathrm{Pen}$, benzo[1,3]dioxol-5-yl, 2-furyl $\mathrm{R}^{3}=\mathrm{H}, \mathrm{OH}, \mathrm{n}=1,2$

$\beta$-Sulfonyl- and $\beta$ sulfinylhydroxamic acids

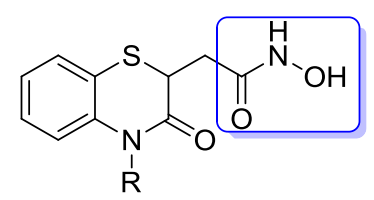

$\mathrm{R}=\mathrm{H}, i$ Pen, Pen, $i$ Hex, phenethyl,

2-methoxyethyl, 2-ethyl-1,3-dioxolane

Benzothiazinone hydroxamic acids

Figure 10

Naturally, there are several other pharmacological uses of hydroxamates and the number of new promising compounds is still increasing.

\subsection{Synthesis of hydroxamic acids by forming a hydroxamic acid functional group}

The first known synthesis of hydroxamic acids was Angeli's procedure developed in 1901. In this method an aromatic aldehyde (1) reacts with sodium nitrohydroxamate (2) (Angeli's 
salt). This transformation is difficult to carry out and the method works only for aromatic compounds and it is not applicable for aliphatic hydroxamates.

At the end of the $19^{\text {th }}$ century Angeli and Rimini discovered that under strong basic conditions hydroxamic acids 3 are formed from $N$-hydroxybenzenesulfonamide (4) and aldehyde $\mathbf{1}$ in good yields. Unfortunately, benzenesulfonic acid by-product (5) was found in this reaction. ${ }^{[48]}$ The synthesis starting from benzaldehyde (1a) is presented in Scheme 2.

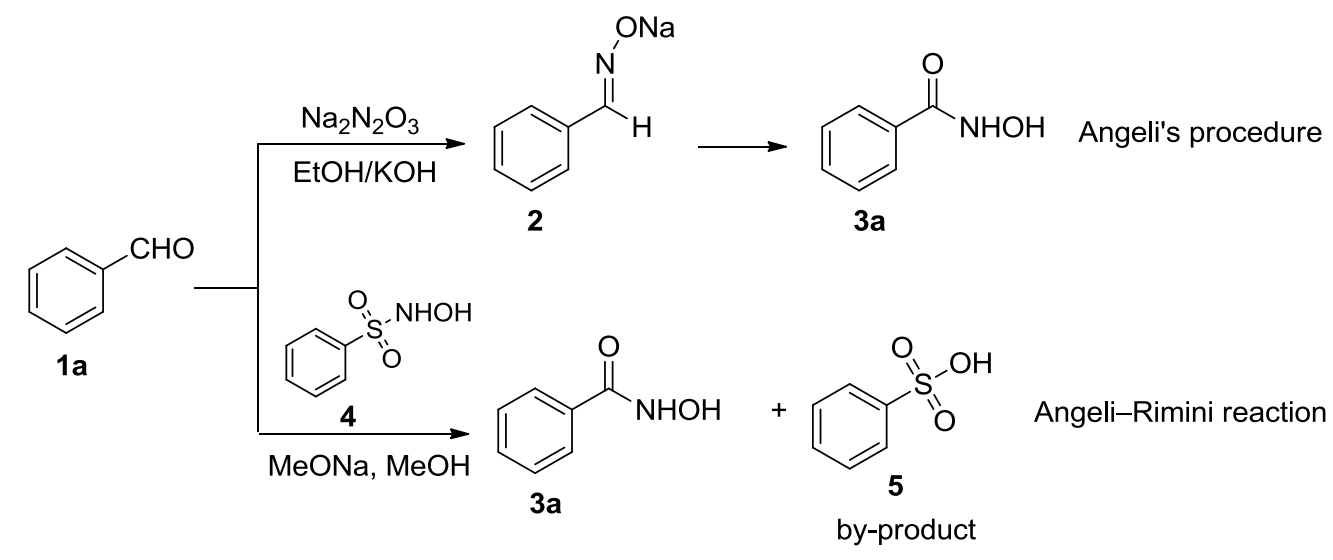

Scheme 2

\subsubsection{Syntheses from carboxylic acid derivatives}

Recently, the most common approach for the synthesis of hydroxamates is the reaction of carboxylic acids ${ }^{[49]}$ or activated carboxylic acid derivatives (esters, ${ }^{[50]}$ mixed anhydrides, ${ }^{[51]}$ acyl chlorides ${ }^{[52]}$ ) and protected ${ }^{[53,54]}$ or unprotected ${ }^{[55]}$ hydroxylamine derivatives under basic conditions. Protected hydroxylamines are highly expensive and there should be an extra step (deprotection) in the end of the synthesis to have the desired product. When using unprotected hydroxylamines, the reaction can lead to $\mathrm{N}, \mathrm{O}$-diacetylated byproducts. $^{[56]}$

Reddy and his colleagues introduced a new synthetic way to produce hydroxamic acids under mild conditions starting from carboxylic acids 6a-j. A typical reaction can be performed with ethyl chloroformate in $\mathrm{Et}_{2} \mathrm{O}$ at $0{ }^{\circ} \mathrm{C}$ to give mixed anhydrides $7 \mathbf{a}-\mathbf{j}$ which, upon treatment with hydroxylamine at ambient temperature, produce hydroxamic acids 3a and $\mathbf{8 b}-\mathbf{j}$. The method is applicable for a wide range of aromatic and aliphatic hydroxamic acids with base-sensitive substituents (hydroxy, halo and ester groups, etc. ${ }^{[51]}$ (Scheme 3 ). 


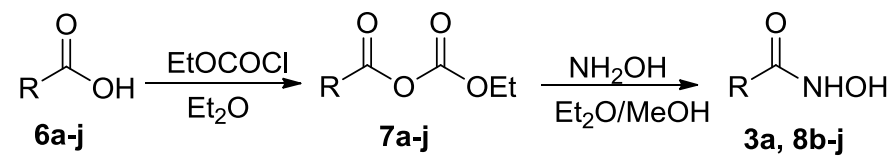

$\mathrm{R}=\mathbf{a}: \mathrm{Ph}, \mathbf{b}: i \mathrm{Pr} \mathbf{c}: \mathrm{Bu}, \mathbf{d}: \mathrm{Pen}, \mathbf{e}: \mathrm{CH}_{2} \mathrm{Br}$, f: $\left(\mathrm{CH}_{2}\right)_{2} \mathrm{Cl}, \mathbf{g}:\left(\mathrm{CH}_{2}\right)_{6} \mathrm{COOEt}$, h: $2-\mathrm{Cl}-\mathrm{C}_{6} \mathrm{H}_{4}$, i: $4-\mathrm{HO}-\mathrm{C}_{6} \mathrm{H}_{4} \mathrm{CH}_{2}$, j: $4-\mathrm{MeO}-\mathrm{C}_{6} \mathrm{H}_{4}$

Scheme 3

Nájera et al. proposed that $S$-(1-oxido-2-pyridinyl)-1,1,3,3-tetramethyluroniumtetrafluoroborate (TOTT) and hexafluorophosphate (HOTT) together with the related new thiouronium salts $S$-(1-oxido-2-pyridinyl)-1,3-dimethylpropyleneuronium tetrafluoroborate (TODT) and the corresponding hexafluorophosphate (HODT) are efficient reagents for the easy, clean and direct preparation of different hydroxamates in high yields. The coupling of different carboxylic acids $6 \mathbf{a}$ and $9 \mathbf{b}, \mathbf{c}$ and $N$-protected $\alpha$-amino acids $9 \mathbf{d}-\mathbf{h}$ with $N, O$ dimethyl-, $O$-methyl- or $O$-benzylhydroxylamine hydrochlorides was carried out in acetonitrile at room temperature with 2 equiv. of trimethylamine in the case of TOTT and HOTT, and in DMF with diisopropylethylamine (DIEA) as base when TODT and HODT were used. The use of these reagents allows the preparation of $O$-methyl hydroxamates with comparable yields and in a more direct and easy manner than using, for instance, acyl chlorides. In the case of $O$-benzyl hydroxamates, yields were similar or even higher when compared to other less direct methodologies. Hexafluorophosphates afforded slightly higher yields $(95 \%)$ than the corresponding tetrafluoroborates $(80-90 \%)$ in the case of undecanoic acid 9b. Products 10-12 were isolated in high yields without racemisation ${ }^{[53]}$ (Scheme 4).<smiles>[R]C(=O)O</smiles>

$6 a, 9 b-h$

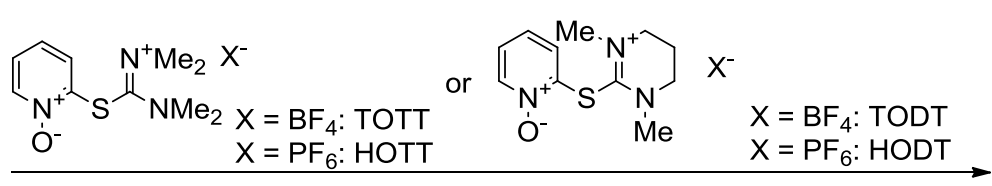

$N, \mathrm{O}$-dimethylhydroxylamine or O-methyl- or O-benzylhydroxylamine hydrochloride, base<smiles>[R]ON([R])C([R])=O</smiles>

$10-12$

10: $R^{2}=R^{3}=$ Me, 11: $R^{2}=H, R^{3}=$ Me, 12: $R^{2}=H, R^{3}=B n$, 6, 9-12: $\mathrm{R}^{1}=\mathbf{a}$ : Phe, b: $\mathrm{CH}_{3}\left(\mathrm{CH}_{2}\right)_{9}, \mathbf{c}: E-\mathrm{C}_{6} \mathrm{H}_{5} \mathrm{CH}=\mathrm{CH}$, d: Boc-Ala, e: Cbz-Ala, f: Fmoc-Ala, g: Cbz-Gly, h: Boc-Phe

Scheme 4

A simple one-pot method was applied by Giacomelli et al. for the synthesis of hydroxamate derivatives of $\alpha$-amino acids and peptides starting from carboxylic acids. Protected carboxylic acids 13-15 were treated with cyanuric acid (2,4,6-trichloro-1,3,5triazine), $N$-methylmorpholine (NMM) and dimethylamino pyridine (DMAP) in 
dichloromethane. Next hydroxylamine hydrochloride was added to the reaction mixture and stirred at room temperature until complete conversion to have protected aminohydroxamic acids 16-18 in high yields and purities ${ }^{[55]}$ (Scheme 5).

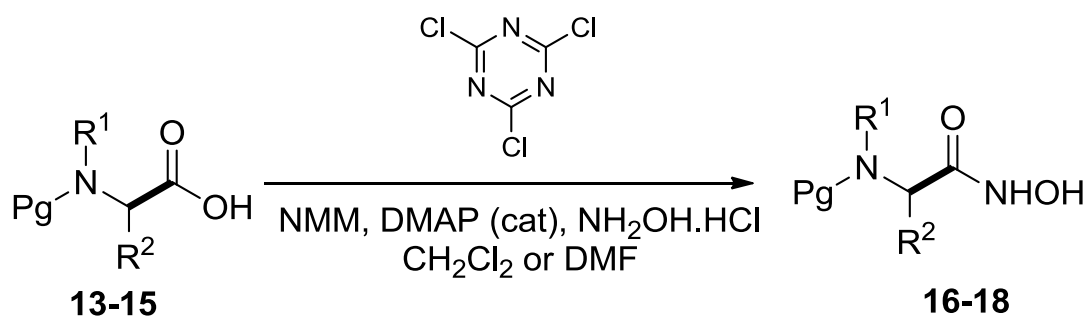

Pg: 13,16: Boc, 14,17: Cbz, 15,18: Fmoc

$\mathrm{R}^{1}=\mathrm{H}: \mathrm{R}^{2}=\mathbf{a}: \mathrm{Me}, \mathbf{b}: i \mathrm{Pr}, \mathbf{c}: \mathrm{CH}_{2} \mathrm{OH}, \mathbf{d}:$ benzyl, e: $\mathrm{CH}_{2} \mathrm{COOBn}, \mathbf{f}: \mathrm{CH}_{2} i \mathrm{Pr}$, $\mathrm{R}^{1}=\mathrm{Me}: \mathrm{R}^{2}=\mathbf{g}: i \mathrm{Pr}, \mathrm{R}^{1}-\mathrm{R}^{2}=\mathbf{h}:-\left(\mathrm{CH}_{2}\right)_{3^{-}}$

Scheme 5

Babu et al. designed a synthesis starting from Fmoc-protected amino acid chlorides 19a-i. First hydroxylamine hydrochloride was dissolved in methanol/water (3:2), treated with $\mathrm{MgO}$ and then acid chlorides 19a-i were added. The mixture stirred at room temperature until completion produced Fmoc-protected hydroxamic acids 18a-c,e,g,i and 20d,f,h ${ }^{[52]}$ (Scheme 6).

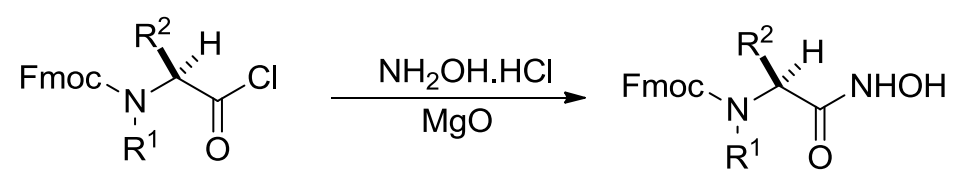

19a-i

18a-c,18e,g,i, 20d,f,h

$$
\begin{gathered}
\mathrm{R}^{1}=\mathrm{H}: \mathrm{R}^{2}=\mathbf{a}: \mathrm{H}, \mathbf{b}: \mathrm{Me}, \mathbf{c}: i \mathrm{Pr}, \mathbf{d}: \mathrm{CH}\left(\mathrm{CH}_{3}\right) \mathrm{CH}_{2} \mathrm{CH}_{3} \text { e: } \mathrm{CH}_{2} \mathrm{C}_{6} \mathrm{H}_{5}, \mathbf{f}: \mathrm{Ph} \text {, } \\
\text { g: } \mathrm{CH}_{2} i \mathrm{Pr}, \mathbf{h}: \mathrm{CH}_{2} \mathrm{OCH}_{2} \mathrm{C}_{6} \mathrm{H}_{5}, \mathrm{R}^{1}-\mathrm{R}^{2}=\mathbf{i}:-\left(\mathrm{CH}_{2}\right)_{3}{ }^{-}
\end{gathered}
$$

Scheme 6

Imai et al. reported the synthesis of primary amides from carboxylic acids, $N$-protected $\alpha$ amino acids, and $\mathrm{N}$-protected dipeptides through the use of mixed carbonic carboxylic anhydrides. Their method is convenient and green because of inexpensive reagents, mild conditions, and safe byproducts, such as triethylamine hydrochloride, carbon dioxide, and the corresponding alcohols. Additionally, they have applied the amidation to prepare various chiral amides containing hydroxamic acid moieties and achieved the synthesis of (1S,2R)-N-Cbz-tranylcypromine (23) (an antidepressant medicine) via Lossen rearrangement ${ }^{[57]}$ (Scheme 7). 


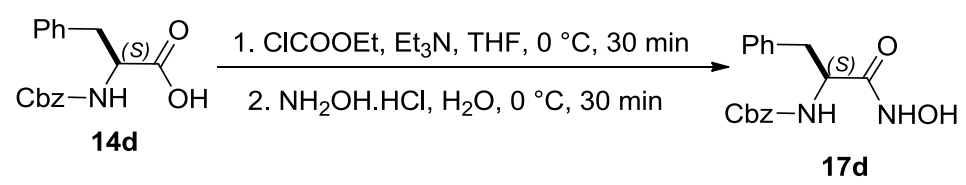

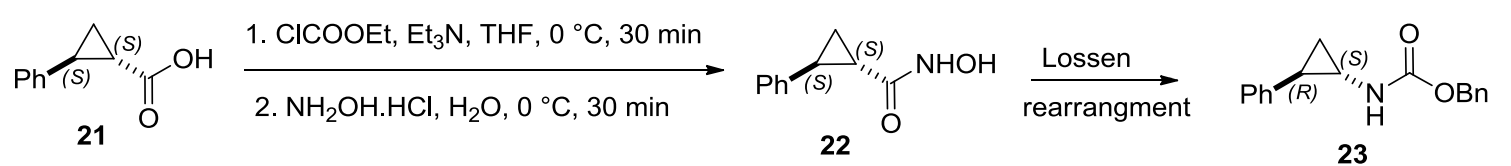

Scheme 7

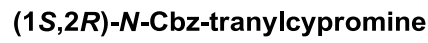

Smissman and his colleagues synthesized unprotected chiral $\alpha$-aminohydroxamic acids (25a-d) starting from 24a-d methyl esters of natural amino acids (L-phenylalanine, Ltyrosin, L-tryptophan, L-histidine) with hydroxylamine hydrochloride under basic conditions. Stereochemical integrity was not affected during the reaction. Optical rotations of the final products (25a-d) were compared and found to be in agreement with literature data $^{[58]}$ (Scheme 8).

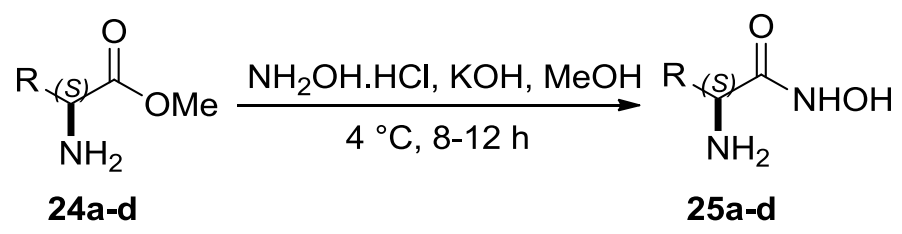

$\mathrm{R}=\mathbf{a}: \mathrm{Ph}, \mathbf{b}: 4-\mathrm{HO}-\mathrm{C}_{6} \mathrm{H}_{4}, \mathbf{c}: 3$-Et- $1 H$-indole, $\mathbf{d}: 1 H$-imidazole

Scheme 8

Löppenberg et al. demonstrated a chiral pool synthesis starting from D-mannono-1,4lacton derivative 27. In the multistep reaction, the $\mathrm{C}-\mathrm{C}$ coupling (Suzuki or Sonogashira) step delivered the structural diversity of the molecules. Finally, desired hydroxamic acids 29a-e and 31e,f were formed via the aminolysis of esters 28a-e and 30a,f with hydroxylamine $^{[59]}$ (Scheme 9).

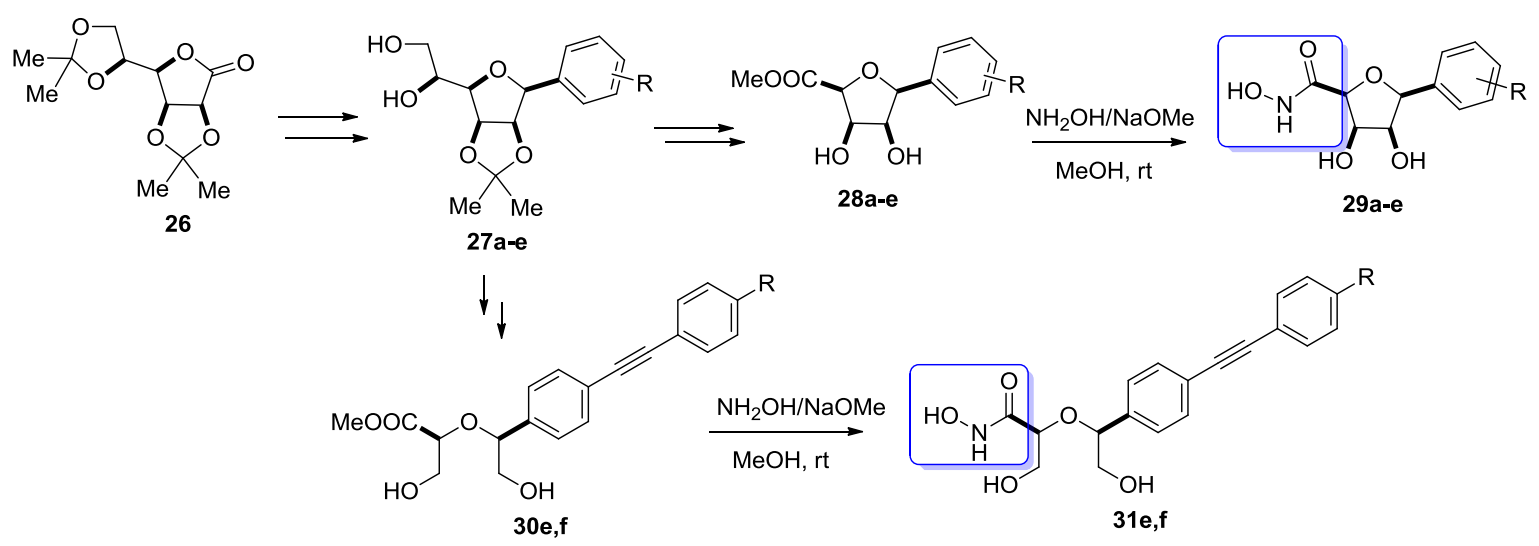

a: $\mathrm{R}=4-\mathrm{I}, \mathbf{b}: \mathrm{R}=3-\mathrm{I}, \mathbf{c}: \mathrm{R}=4-\mathrm{Br}, \mathbf{d}: \mathrm{R}=3-\mathrm{Br}, \mathbf{e}: \mathrm{R}=\mathrm{H}, \mathbf{f}: \mathrm{R}=\mathrm{N}-\mathrm{CH}_{2}-$ morpholine

Scheme 9 


\subsubsection{Enabling techniques ${ }^{[60]}$ for the synthesis of hydroxamic acids}

Nowadays most of the syntheses of hydroxamic acids are carried out in a classical way, (batch reactions) but there can be found some enabling methods. These techniques reduce reaction time, ease the work up and isolation of products. Enabling synthesis can be achieved on solid supports ${ }^{[61,62]}$ by microwave acceleration ${ }^{[50]}$ or in continuous flow system $^{[63]}$.

\subsubsection{Synthesis by microwave acceleration}

Microwave irradiation speeds up reactions by a simple and efficient heating of the system. ${ }^{[64]}$

Mordini et al. published a microwave-assisted method for the synthesis of hydroxamic acids 3a, 16a,d and 32d-j. In the first step, methyl esters 31a-j were dissolved in anhydrous methanol under nitrogen followed by the addition of hydroxylamine hydrochloride and $\mathrm{KOH}$ to the reaction mixture. Then the reaction vessel was sealed and inserted to the microwave reactor and stirred for $6 \mathrm{~min}$ at $80{ }^{\circ} \mathrm{C}$. The synthesis has good tolerance for a range of functional groups and it is suitable for the synthesis of enantiomerically pure esters as well without the loss of stereochemical integrity ${ }^{[50]}$ (Scheme 10).

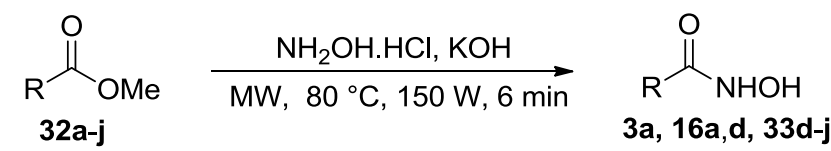

a: Ph, b: Boc-Ala, c: Boc-Phe, d: S-Pro, e: Boc-Pro,

f: $(S)$-t-butyl 2,2-dimethyloxazolidine-3-carboxylate, g: $t$-butyl $(S)-1-[(S)$-2-phenylethylcarbamoyl]-2-methylpropylcarbamate h: $(S)$-3-(benzylthio)-2-((furan-2-ylmethyl)(i-butyl)amino)-1-((R)-2-methylpiperidin-1yl)propan-1-one, i: $(R)-2,2,4-$ trimethyl-1,3-dioxolane, $\mathbf{j}$ : 1-(ethylsulfonyl)-4methoxybenzene

\section{Scheme 10}

Kurz et al. developed an efficient, fast and convenient method for the microwave-assisted synthesis of various $O$-protected hydroxamic acids (35a-o). The reactions of 4-nitrophenyl esters 33a-g and $O$-protected hydroxylamines ( $O$-benzyl-, $O$-1-naphtylmethyl-, $O$-3,4dimethyloxybenzyl-, $O$-tetrahydropyranyl-hydroxylamine) were performed in dry toluene with catalytic amount of glacial acetic acid in sealed reaction vessel in the presence of different bases (e.g. TEA, DMAP). Microwave irradiation afforded the corresponding $O$ substituted hydroxamic acids 35a-o in yields of 39-94\% in 10-20 min $^{[64]}$ (Scheme 11). 


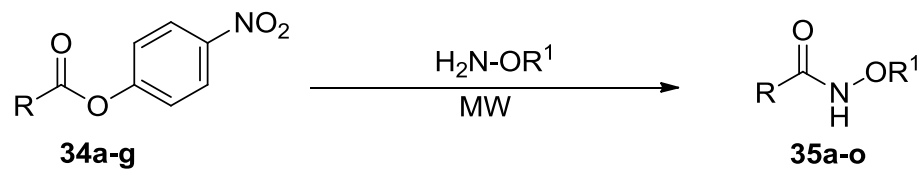

$34 \mathrm{R}=\mathbf{a}: \mathrm{Ph}, \mathbf{b}$ : furyl, c: naphthyl, d: $p$-(Cbz-amino)-phenyl, e: $\mathrm{Me}, \mathbf{f}: t-\mathrm{Bu}$, g: furyl h: Bn

35 a: $\mathrm{R}=\mathrm{Ph}, \mathrm{R}^{1}=\mathrm{Bn}, \mathbf{b}: \mathrm{R}=$ furyl, $\mathrm{R}^{1}=\mathrm{Bn}, \mathbf{c}: \mathrm{R}=$ naphthyl, $\mathbf{d}: \mathrm{R}=p$-(Cbz-amino)-phenyl, $\mathrm{R}^{1}=\mathrm{Bn}, \mathbf{e}: \mathrm{R}=\mathrm{Me}, \mathrm{R}^{1}=$ naphthyl, $\mathbf{f}: \mathrm{R}=t-\mathrm{Bu}, \mathrm{R}^{1}=$ naphthyl, $\mathbf{g}: \mathrm{R}=$ furyl, $\mathrm{R}^{1}=$ naphthyl, $\mathbf{h}:$

$\mathrm{R}=\mathrm{Ph}, \mathrm{R}^{1}=$ naphthyl, $\mathbf{i}: \mathrm{R}=\mathrm{Bn}, \mathrm{R}^{1}=3,4$-dimethoxybenzyl, $\mathbf{j}: \mathrm{R}=$ furyl, $\mathrm{R}^{1}=3,4-$

dimethoxybenzyl, $\mathbf{k}: \mathrm{R}=$ naphthyl, $\mathrm{R}^{1}=3$,4-dimethoxybenzyl, $\mathbf{l}: \mathrm{R}=$ methyl, $\mathrm{R}^{1}=3,4-$ dimethoxybenzyl, $\mathbf{m}: \mathrm{R}=\mathrm{Ph}, \mathrm{R}^{1}=3,4$-dimethoxybenzyl, $\mathbf{n}: \mathrm{R}=\mathrm{Ph}, \mathrm{R}^{1}=$ tetrahydropyranyl, o: $\mathrm{R}=\mathrm{Bn}, \mathrm{R}^{1}=$ tetrahydropyranyl

Scheme 11

\subsubsection{Continuous flow systems}

Reactions in continuous flow systems have great advantages like precise control of conditions (temperature, pressure, concentration, and residence time), improved yields and selectivity and easy scale-up. ${ }^{[63]}$

Martinelli et al. elaborated a continuous flow method to transform aliphatic, aromatic and heteroaromatic carboxylic esters into the corresponding hydroxamic acids. The process were investigated by varying flow rate, temperature and reaction volume. After optimalisation the method was extended to the total synthesis of SAHA (38). In the first step methyl suberoyl chloride $\mathbf{3 6}$ and aniline gave intermediate $\mathbf{3 7}$, which was treated with hydroxylamine under basic conditions. During the procedure a carboxylic acid by-product was formed. With the aim of avoiding time-consuming manual purification, a short packed column containing silica-supported quaternary amine (ISOLUTE PE-AX ${ }^{\circledR}$ ) was inserted directly in the reaction stream. Suberoylanilide hydroxamic acid (SAHA, 38) was obtained in $80 \%$ yield and with $99 \%$ purity $^{[63]}$ (Scheme 12).

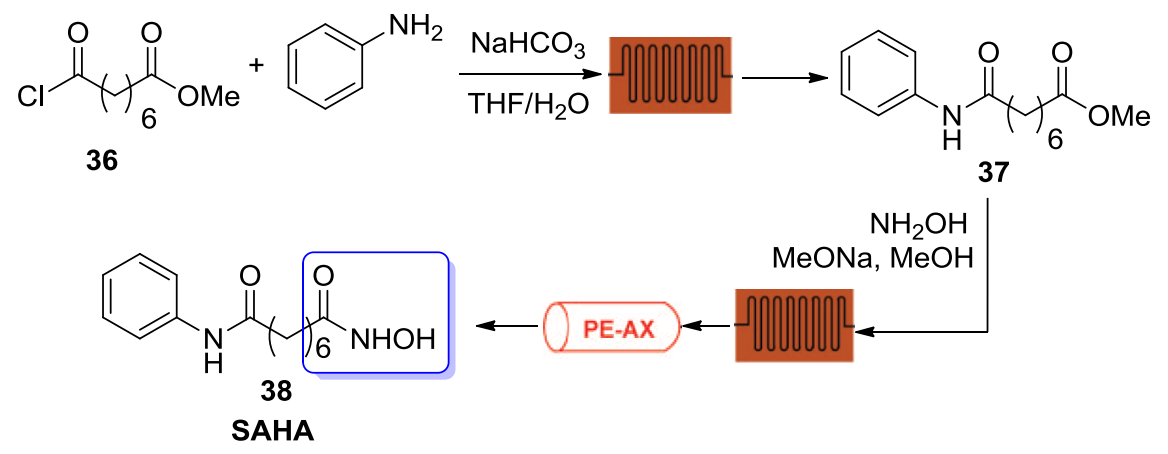

Scheme 12 


\subsubsection{Synthesis on solid support}

Solid-phase synthesis is a popular tool in preparation of peptide and oligonucleic acid libraries $^{[60]}$, but it is a useful method for the syntheses of hydroxamic acids as well. For instance, Taddei et al. designed the solid-phase synthesis of conformationally constrained peptidomimetics $\mathbf{4 3}$ based on a 3,6-disubstituted-1,4-diazepan-2,5-dione core.

For the solid-phase approach, the authors selected hydroxylamine linked to a PS-DVB 2chlorotrytyl resin (39). Coupling with FmocPheOH gave hydroxamate 40 (Scheme 12). Mitsunobu cyclisation was carried out in DMF as solvent, in the presence of 2 equiv. of DIAD and 4 equiv. of $\mathrm{PPh}_{3}$ in a sealed tube under microwave irradiation $\left(60 \mathrm{~W}, 210{ }^{\circ} \mathrm{C}\right)$. After $6 \mathrm{~min}$, the beads were recovered by filtration, washed several times with DMF and $\mathrm{CH}_{2} \mathrm{Cl}_{2}$, and submitted to a second round of reaction under the same conditions. After 3 cycles, the colour test for free OH18 carried out with the beads was negative. The Fmoc protecting group was removed, the formed $\mathrm{NH}_{2}$ function was acetylated to simplify the NMR spectra, and product 42 was removed from the resin with TFA/ $\mathrm{CH}_{2} \mathrm{Cl}_{2} 1 / 1$ and isolated in $66 \%$ yield.

This heterocycle can be employed as a new scaffold for combinatorial chemistry and as conformational constrains for short peptides ${ }^{[62]}$ (Scheme 13).

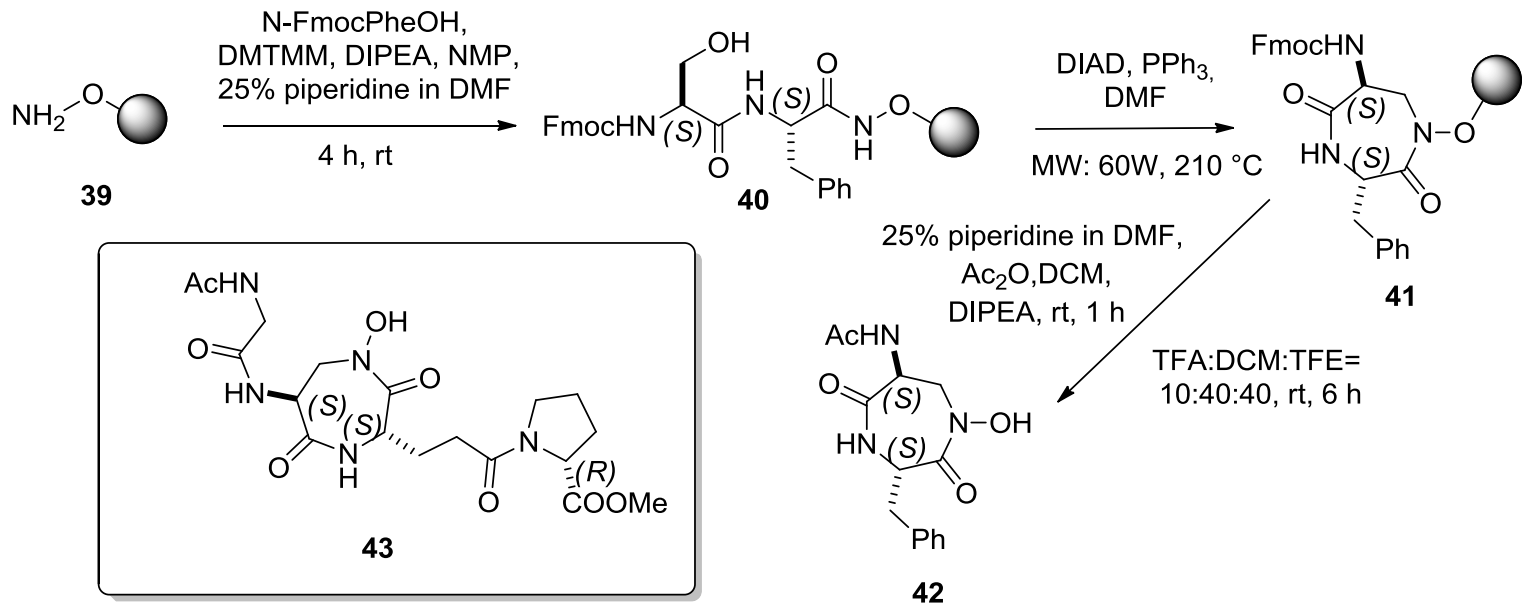

Scheme 13

\subsection{Synthesis of aromatic and alicyclic $\beta$-amino hydroxamic acids}

A library of $\mathbf{2 9}$ anthranilic hydroxamic acid (AHA) derivatives containing a wide range of substituents with different electronic and steric properties has been prepared and tested by Lee and coworkers. ${ }^{[65]}$ The general strategy was to prepare novel AHA compounds $\mathbf{4 8}$ and 49 by solid-phase synthesis from commercially available carboxylic acid precursors $\mathbf{4 5}$ and 46, without the need to protect the anilino group. An attractive solution is to use this latter 
function for the attachment of anthranilic acid to the resin, and to subsequently convert the free carboxylic group to the hydroxamate function by simple coupling chemistry with hydroxylamine. Hydroxamic acids were obtained in quantitative yields and with high purities (Scheme 14).

The currently available non-steroidal anti-inflammatory drugs (NSAIDs) such as aspirin are directed at the cyclooxygenase (COX) site, but not the peroxidase (POX) activity of prostaglandin $\mathrm{H}_{2}$ synthase (PGHS). They are thus unable to inhibit tissue injury associated with PGHS peroxidase activity induced by free-radicals, which can occur independently of the COX site. A lead compound, anthranilic hydroxamic acid (48a, AHA) was found to have significant PGHS-POX inhibitory activity $\left(\mathrm{IC}_{50}=72 \mu \mathrm{M}\right)$. To define the critical parameters for PGHS-POX inhibition, the authors investigated 29 AHA derivatives. In contrast to other peroxidases, PGHS-1 appears to favour an amino group at the ortho position in the aromatic hydroxamic acid peroxidase inhibitors, i.e. AHA. Derivatisation showed that substituents ortho and para to the amino group, i.e. meta to the hydroxamic acid group, are preferred, with electron-withdrawing or polarisable substituents significantly improving inhibition. Electron-donating groups, however, consistently decrease efficacy. All aromatic hydroxamic acid peroxidase inhibitors tested showed significant co-substrate activity, except for 3,5-diiodo-AHA, which appears to be a true PGHS-1 peroxidase inhibitor. In vitro analysis demonstrated a ten-fold improvement in inhibition with 3,5-diiodo-AHA ( $\left.\mathrm{IC}_{50}=7 \mu \mathrm{M}\right)$.

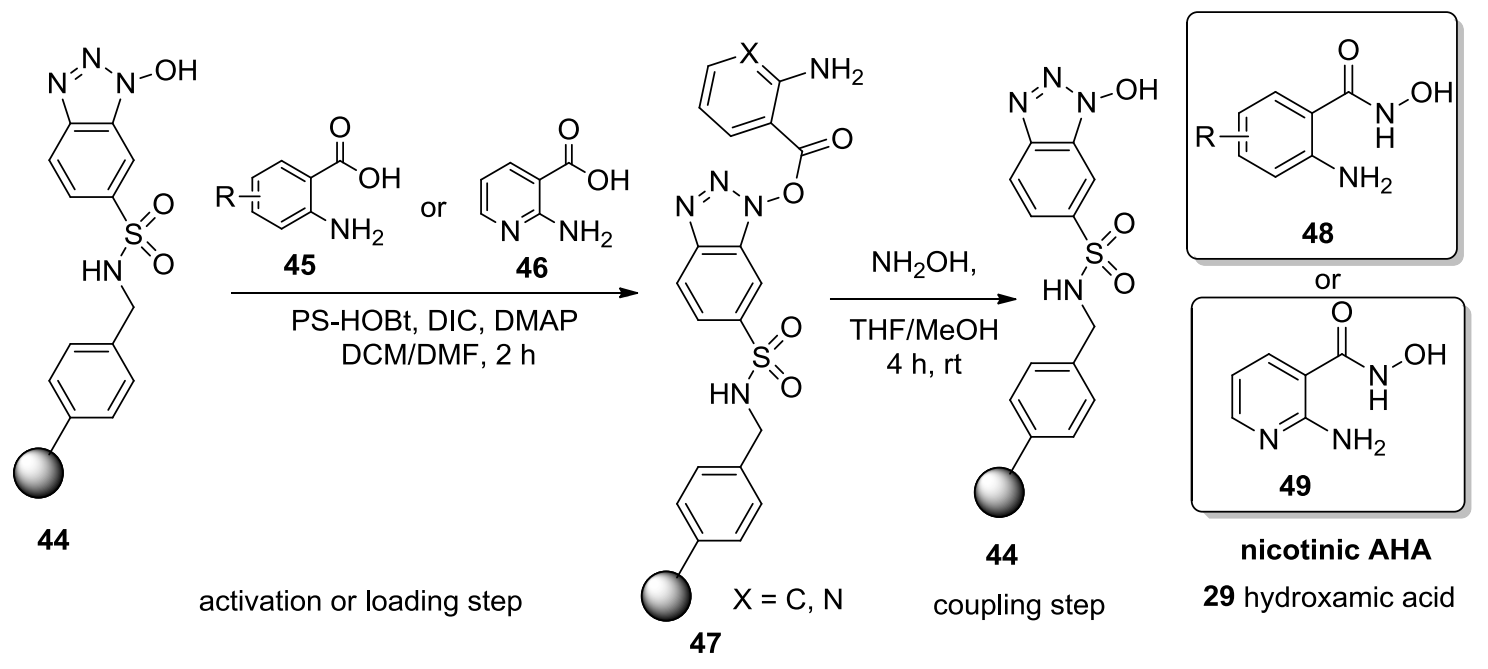

$\mathrm{R}=\mathrm{H}, 3-\mathrm{Cl}, 3-\mathrm{OMe}, 3-\mathrm{CF}_{3}, 4-\mathrm{Cl}, 4-\mathrm{F}, 4-\mathrm{NO}_{2}, 5-\mathrm{NHCOMe}$

5-Br, 5-Cl, 5-F, 5-OH, 5-I, 5-OMe, 5-Me, 5- $\mathrm{NO}_{2}, 6-\mathrm{Cl}$,

6-F, 6-Me, 3,5-Cl, 3,5-Br, 3,5-I, 3,5-Me,

3-Br-5-Me, 3,4,5-OMe, 3,4,5,6-F, 4,5-F, 4,5-OMe

Scheme 14 
According to the literature, the synthesis of anthranilic hydroxamic acid derivatives (50a-m) directly from esters $(\mathbf{4 8 a}-\mathbf{m})$ with hydroxylamine has been widely examined by several research groups ${ }^{[66]}$ (Scheme 15).

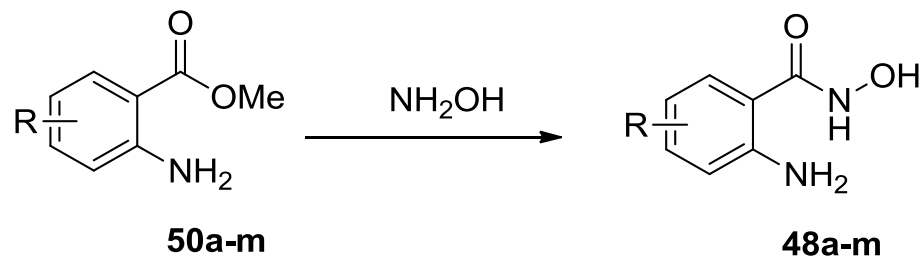

$\mathrm{R}=\mathbf{a}: \mathrm{H}, \mathbf{b}:$ 4-F, c: 5-Br, d: 5-Cl, e: 5-F, f: 5-I, g: 3-Me, h: 5-Me, i: 3,5-Br, j: 3,5-Cl, k: 3,5-I, l: 3,4-Me, m: 5-Ph

Scheme 15

There are examples for the synthesis of 48a and 48n starting from 2-amino-4chlorobenzonitrile $(\mathbf{5 1})^{[67]}$, 2-nitrobenzoic acid $(\mathbf{5 2})^{[68]}$ or isatoic anhydride $(\mathbf{5 3})^{[69]}$ as well (Scheme 16).<smiles>N#Cc1ccc(Cl)cc1N</smiles>

51
$\frac{\mathrm{NaHCO}_{3}, \mathrm{NH}_{2} \mathrm{OH} . \mathrm{HCl},}{\text { EtOH, } 8 \text { h, reflux }}$

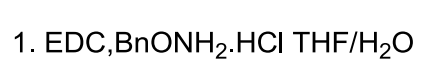

2. $\mathrm{H}_{2}, \mathrm{Pd} / \mathrm{C}$<smiles>O=C(O)c1ccccc1[N+](=O)[O-]</smiles>

52<smiles>[R]c1ccc(C(=O)NO)c(N)c1</smiles>

48a: $\mathrm{R}=\mathrm{H}, 48 \mathrm{n}: \mathrm{R}=\mathrm{Cl}$

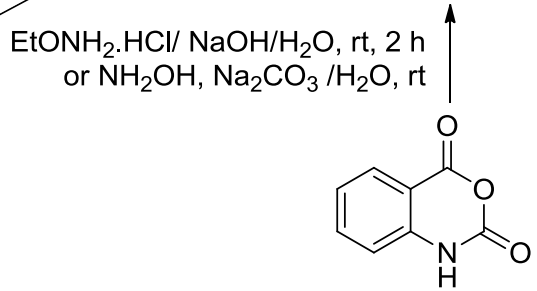

53

Scheme 16

The synthesis of alicyclic $\beta$-aminohydroxamic acid derivatives $\mathbf{5 6}$ designed by Davies $e t$ $a l$. was performed in two steps. First $N$-sulfinimines 54 were reacted with Weinreb amides in the presence of lithium diisopropylamide (LDA) producing $N$-sulfinyl- $\beta$-aminodiene Weinreb amides 55. Ring-closing metathesis reaction of the products achieved with Grubbs II catalyst resulted in $\mathbf{5 6}^{[70]}$ (Scheme 17).

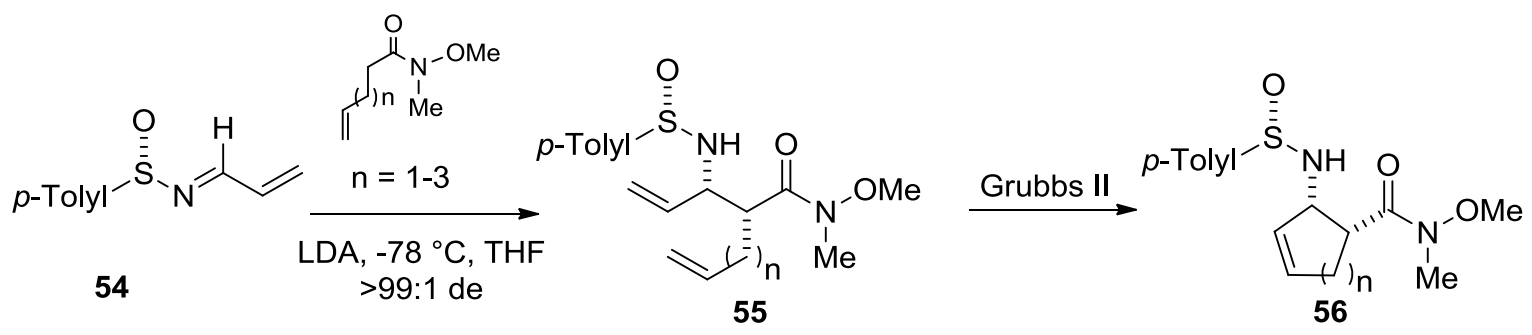

Scheme 17 


\subsection{Ring-closure reaction of anthranilic hydroxamic acids}

Contrary to the wide range of possibilities for the use of hydroxamic acids in developing new therapeutic agents, there is only limited information about their ring-closing reactions in the literature. In most of the cases, the moiety is built in in the last step of the syntheses and these methods do not provide any information about the reactivity of the hydroxamic acids. In this section, a few cyclisations of AHA derivatives are presented.

Shemchuck et al. examined the reaction of AHA (48a) and 2-aminobenzamide (57) with cyclic anhydrides and compared their reactivity. Anthranilic acid amide $\mathbf{5 7}$ was reacted with cyclic anhydrides to give the corresponding amino $N$-acyl derivatives 58a-c, while the analogues reactions of AHA 48a led to the formation of 3-quinazolin-4-ones 61a-c under mild conditions. $\mathrm{N}$-Acyl derivatives of anthranilic acid amide underwent intramolecular cyclisation to imides on microwave irradiation or on melting, and their treatment with acetic anhydride in the presence of sodium acetate on heating for a short time yielded quinazolin-4-ones 59a-c. Prolonged reaction in $60 \mathrm{~min}$ resulted in lactams 60a-c, whereas the reactions of 61a-c with sodium acetate gave lactones 62a-c. The observed difference in the reaction paths of AHA 48a and amide 57 with cyclic anhydrides may be interpreted on the basis of different nucleophilicities of amide and $\mathrm{N}$-hydroxyamide groups. Note that hydroxamic acids exhibit enhanced nucleophilicity due to the $\alpha$-effect ${ }^{[71]}$ (Scheme 18).
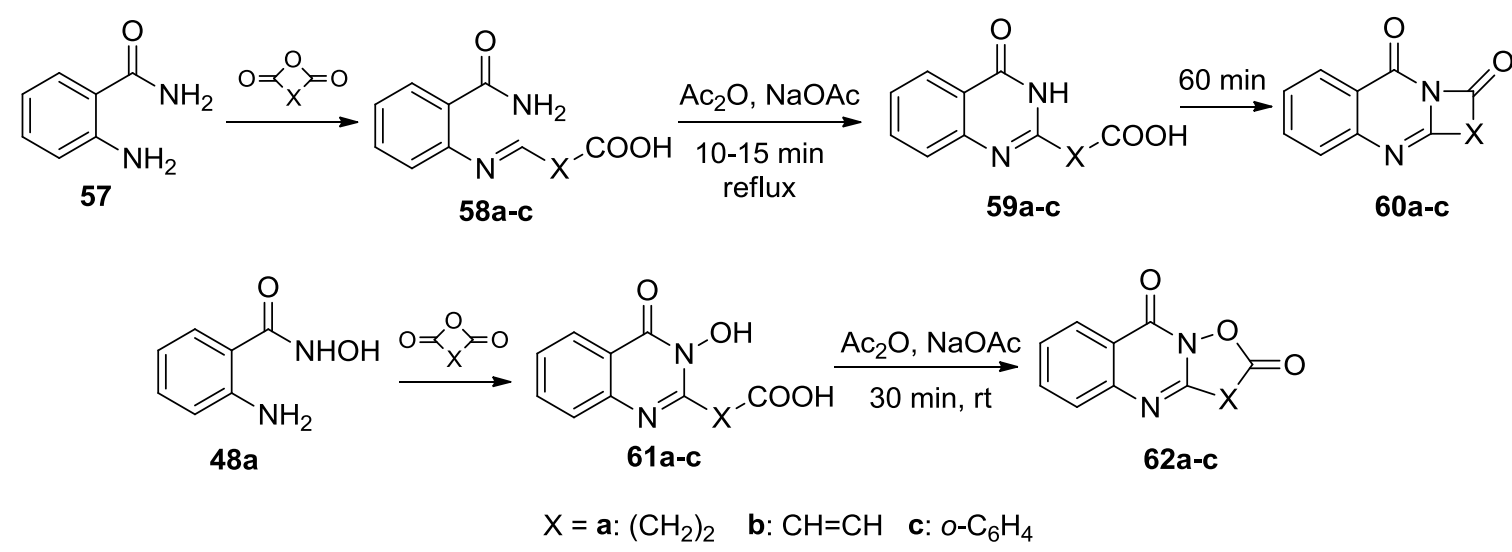

Scheme 18

To find a new compound to replace HOBt in peptide synthesis, Shpernat et al. designed the preparation of 3-hydroxybenzo[ $[d][1,2,3]$ triazin- $4(3 \mathrm{H})$-one $(\mathbf{6 3})$. The desired product was gained in the reaction of AHA and sodium nitrite. ${ }^{[66 b]}$

$\mathrm{N}$-Hydroxyquinazolinedione 64, a potential NMDA receptor antagonist for the treatment of stroke and other neurodegenerative disorders, was prepared by Romine and his coworkers starting from AHA and ethyl chloroformate. ${ }^{[72]}$ 
Zhao et al. introduced a simple method to synthesize a variety of $4(3 H)$-quinazolinones $(\mathbf{6 6} \mathbf{a}, \mathbf{b})$ in the reaction of $N$-methyl or $N$-benzyl derivatives of AHA $65 \mathbf{a}, \mathbf{b}$ and aldehydes via cyclisation in the presence of catalytic amount of $p$-TSA followed by oxidation with iodosobenzene diacetate. There are several methods to synthesize quinazolinones but there are only a few examples for $\mathrm{N}$-alkoxyquinazolinones contrary to some indole-based pharmaceuticals showing improved biological activity with $N$-methoxy substitution. ${ }^{[73]}$ ElFaham et al. proposed the use of one or two new $N$-containing $N$-hydroxy heterocycles in peptide syntheses, which are not explosive like HOBt. $\mathrm{N}-\mathrm{O}$-Benzyl-protected $\mathbf{6 5} \mathbf{b}$ and $\mathbf{6 6}$ or unprotected hydroxamic acids $\mathbf{4 8 a}, \mathbf{d}$ were reacted with acetic anhydride or formic acid to produce the desired products $6 \mathbf{6 7}$-f with excellent yields ${ }^{[69]}$ (Table 1).

Table 1. Reagents and conditions of the ring closure of anthranilic hydroxamic acids

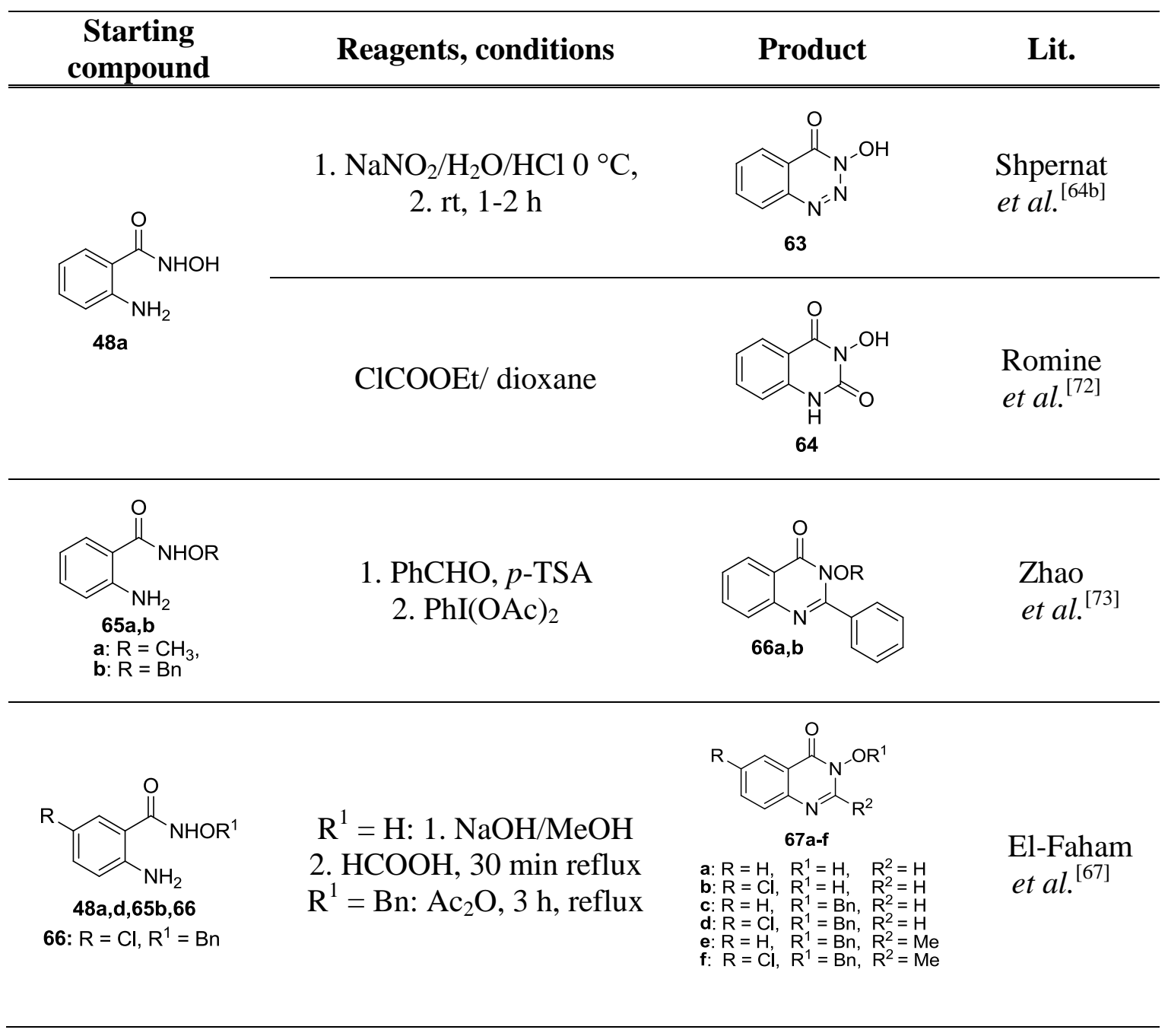




\section{RESULTS AND DISCUSSION}

\subsection{Synthesis of new racemic alicyclic $\beta$-aminohydroxamic acids}

Contrary to the well-documented synthesis of aromatic ${ }^{[68,74]}$ and alkyl hydroxamic acids ${ }^{[75]}$, there is only limited information about the corresponding alicyclic compounds ${ }^{[76]}$. We have designed the syntheses of new racemic cis- and trans-2-aminocyclohexane-hydroxamic acids, cis- and trans-2-aminocyclohex-4-ene-hydroxamic acids, diendo- and diexo-3aminobicyclo[2.2.1] hept-5-ene-2-hydroxamic acids and diendo- and diexo-3aminobicyclo[2.2.1] heptane-2-hydroxamic acids starting from the appropriate esters.

Initially, the hydrochloride salts of the corresponding esters $( \pm)-68-( \pm)-74$ and hydroxylamine hydrochloride were dissolved in ethanol then the $\mathrm{pH}$ was adjusted to 13 by the addition of aqueous $\mathrm{NaOH}$ solution. In these cases, highly hygroscopic products were formed but purification was extremely difficult. Furthermore, due to the basic $\mathrm{pH}$, ester hydrolysis was also observed and, consequently, amino acid by-products appeared in the reaction mixture. When 3 equiv. of commercially available $50 \mathrm{w} / \mathrm{w} \%$ aqueous hydroxylamine solution were used under neutral $\mathrm{pH}$ (ambient temperature, $24 \mathrm{~h}$ ), instead of hydroxylamine hydrochloride under basic conditions, products $( \pm)-\mathbf{7 5 -}( \pm)-\mathbf{8 2}$ were isolated in high yields (79-93\%) [I]. The syntheses repeated under the same conditions starting from appropriate lactams $( \pm)-\mathbf{8 3}-( \pm)-\mathbf{8 6}{ }^{[76]}$ resulted in hydroxamic acids $( \pm)$-75( \pm )-82, but product yields were lower (79-93\% vs. 43-76\%). (Scheme 19 and Table 2)

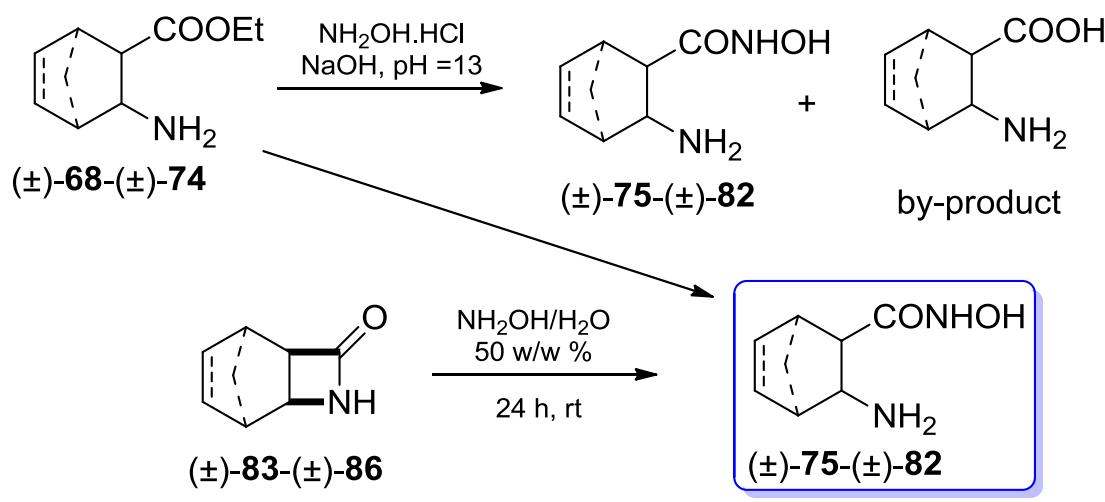

Scheme 19 
Table 2. Numbering and structure of the compounds in Scheme 20.

\begin{tabular}{|c|c|c|c|}
\hline structure & $\begin{array}{c}\text { esters } \\
\mathrm{R}^{1}=\mathrm{COOEt}, \mathrm{R}^{2}=\mathrm{NH}_{2}\end{array}$ & $\begin{array}{c}\text { hydroxamic acids } \\
\mathrm{R}^{1}=\mathrm{CONHOH} \\
\mathrm{R}^{2}=\mathrm{NH}_{2}\end{array}$ & $\begin{array}{c}\text { lactams } \\
\mathrm{R}^{1}-\mathrm{R}^{2}=\mathrm{CONH}\end{array}$ \\
\hline & $( \pm)-68$ & $( \pm)-75$ & $( \pm)-83$ \\
\hline & $( \pm)-69$ & $( \pm)-76$ & $( \pm)-84$ \\
\hline & $( \pm)-\mathbf{7 0}$ & $( \pm)-77$ & - \\
\hline & $( \pm)-71$ & $( \pm)-78$ & - \\
\hline & $( \pm)-72$ & $( \pm)-79$ & - \\
\hline & - & $( \pm)-80$ & - \\
\hline & $( \pm)-73$ & $( \pm)-81$ & $( \pm)-85$ \\
\hline & $( \pm)-74$ & $( \pm)-82$ & $( \pm)-86$ \\
\hline
\end{tabular}

\subsection{Synthesis of new enantiomerically enriched alicyclic $\beta$-aminohydroxamic acids}

Many attractive techniques are available for the production of enantiomerically pure amino acid derivatives. ${ }^{[77]}$ Resolution via diastereomeric salt formation, for instance, is still useful for the production of enantiomerically pure esters on a laboratory scale. ${ }^{[78]}$ Resolution with one equiv. of the resolving agent (Pasteur's method) is the most convenient when working with small amounts of the racemate. ${ }^{[79]}$ If there is a large difference in stability of the 
resulting diastereomeric salt and the enantiomer remaining in solution, resolutions may be performed with half an equivalent of resolving agent. To find the most suitable resolving agent for esters $( \pm)-68-( \pm)-74$, three kinds of commercially available acidic resolving agents were examined. We used half an equivalent of $O, O^{\prime}$-dibenzoyltartaric acid (DBTA), $O, O^{\prime}$-di- $p$-toluoyltartaric acid (DPTTA) and $S$-mandelic acid as resolving agents often used in gram-scale productions. ${ }^{[80]}$ The solvent in each resolution experiment was EtOH. As the ${ }^{1} \mathrm{H}-\mathrm{NMR}$ spectra of the salt pairs were identical, the diastereomeric purity of the salt obtained in each resolution experiment was determined as the diastereomeric excess ( $d e \%)$, based on the enantiomeric excess $(e e \%)$ of ester in the salt. After liberation of the diasteromeric salts, the free ester bases were treated with hydroxylamine solution as previously described.

\section{Resolution of ethyl cis- and trans-2-aminocyclohex-4-ene-carboxylates (( \pm$)-68,(( \pm)-70)$}

In the preliminary experiments, racemic ethyl cis-2-aminocyclohex-4-enecarboxylate $(( \pm)-68)$ and ethyl trans-2-aminocyclohex-4-enecarboxylate $((+)-70)$ were dissolved at 70 ${ }^{\circ} \mathrm{C}$ in $\mathrm{EtOH}$ and half equivalent commercially available (+)-O, $O^{\prime}$-di-benzoyltartaric acid $((+)$-DBTA $), \quad(-)-O, O^{\prime}$-di-p-toluoyltartaric acid $\quad((-)$-DPPTA $) \quad$ or $\quad(S)-(+)-\alpha-$ hydroxyphenylacetic acid $(S$-(+)-mandelic acid) was added and the solutions were left to cool to room temperature. The resulting white crystals were filtered off and washed once with $\mathrm{Et}_{2} \mathrm{O}$. The ee values were determined by HPLC measurements. The absolute configurations were proved by comparing the literature data of optical rotations ${ }^{[81,82]}$ with the measured values (see in Schemes 20, 21 and Table 3). Resolution with $S$-(+)-mandelic acid gave the highest yields and $e e$ in both cases.

Synthesis of ethyl (1R,2S)-2-aminocyclohexanecarboxylate ((-)-69) and ethyl (1R,2R)-2aminocyclohexanecarboxylate ((-)-71) enantiomers

Initially, the resolution of $( \pm)-69$ and $( \pm)-71$ was performed using the same conditions described above. However, poor ee values (20-37\%) were obtained with DBTA, DPTTA and $S$-mandelic acid in both EtOH and EtOAc. Catalytic hydrogenation of the double bond of ester enantiomers (-)-68 and (-)-70 was an alternative possibility. Starting compounds (-)-68 and (-)-70 were treated with $\mathrm{H}_{2}$ in the presence of $\mathrm{Pd} / \mathrm{C}$ in continuous flow system. The optical rotation of saturated amino ester enantiomers was compared with known literature values ${ }^{[82,83]}$ (Scheme 21, 22 and Table 3). Catalytic hydrogenation of (-)-68 and $(-)-70$ provided (-)-69 and (-)-71 with acceptable ee values. Hydroxamic acids (-)-75, 
(+)-76, (-)-77 and (+)-78 were produced by treating ester enantiomers with $50 \mathrm{w} / \mathrm{w} \%$ aqueous hydroxylamine solution at ambient temperature as described above.

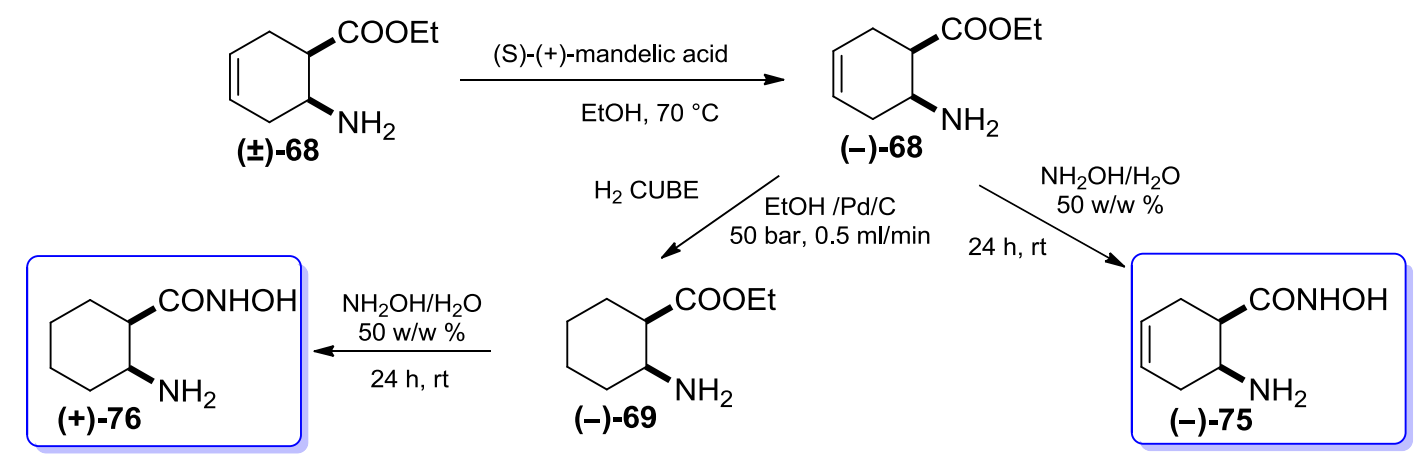

Scheme 20

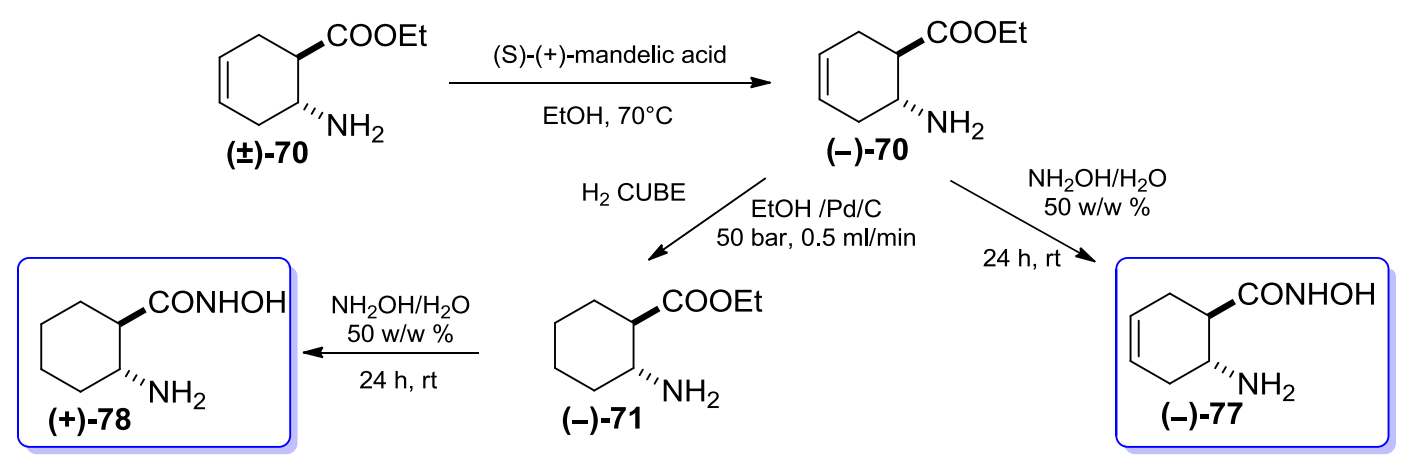

Scheme 21 
Table 3. Optical rotation data of the ester and 2-aminohydroxamic acid enantiomers

\begin{tabular}{|c|c|c|c|}
\hline $\begin{array}{c}\text { Starting ester } \\
\text { enantiomers } \\
(e e)\end{array}$ & $\begin{array}{l}\text { Optical rotation of ester } \\
\text { enantiomers in EtOH } \\
\text { (literature data) }\end{array}$ & $\begin{array}{c}\text { Structure of } \\
\text { hydroxamic } \\
\text { acid enantiomers }\end{array}$ & $\begin{array}{l}\text { Optical rotation of } \\
\text { hydroxamic acid } \\
\text { enantiomers in } \mathrm{H}_{2} \mathrm{O}\end{array}$ \\
\hline $\begin{array}{c}(-)-68 \\
98 \%\end{array}$ & $\begin{array}{l}-18.9, \mathrm{c}=1 \\
(\text { antipode: }+19: \mathrm{c}=1)^{[81]}\end{array}$ & $\begin{array}{l}\text { (S) } \mathrm{NH}_{2} \\
(-)-75\end{array}$ & $-13, c=0.50$ \\
\hline $\begin{array}{c}(-)-69 \\
98 \%\end{array}$ & $\begin{array}{c}-2.4, \mathrm{c}=1 \\
(-2.7, \mathrm{c}=1)^{[83]}\end{array}$ & $\int_{(S)}^{(R)} \mathrm{NH}_{2}$ & $+10, c=0.50$ \\
\hline $\begin{array}{c}(-)-70 \\
97 \%\end{array}$ & $\begin{array}{c}-99, \mathrm{c}=0.75 \\
(-120, \mathrm{c}=0.75)^{[82]}\end{array}$ & $\begin{array}{l}\text { (R) } \mathrm{NH}_{2} \\
(-)-77\end{array}$ & $-42, c=0.50$ \\
\hline $\begin{array}{c}(-)-71 \\
97 \%\end{array}$ & $\begin{array}{c}-53.9, c=1 \\
(\text { antipode: }+46, c=1)^{[84]}\end{array}$ & $\begin{array}{l}\left.l^{\prime \prime \prime}\right)^{\prime \prime} \mathrm{NH}_{2} \\
(+)-78\end{array}$ & $+36, c=0.50$ \\
\hline
\end{tabular}

Resolution of ethyl diendo- and diexo-3-aminobicyclo[2.2.1]hept-5-ene-2-carboxylate $(( \pm)-72$ and $( \pm)-73)$

$S$-Mandelic acid, DPTTA and DBTA in EtOAc and EtOH were examined as described above with the cyclohexane and cyclohexene derivatives. The use of half equivalent of DBTA in EtOH with diendo $( \pm)-72$ and half equivalent of DPTTA in EtOH with diexo $( \pm)-\mathbf{7 3}$ was found to be optimal, with an appropriate solvent volume determined by the solubility of the solid substances at $70{ }^{\circ} \mathrm{C}$ in each resolution experiment. The diastereomeric excesses of these salts could be improved by a single recrystallisation from EtOH to have $d e$ values of $92-99 \%$. The $e e$ values for (+)-72 and (-)-72 were determined by gas chromatography on a Chromopak Chiralsil-Dex CB column. [I] Compounds (+)-79, $(-)-79,(+)-81$ and $(-)-81$ were produced by the aminolysis of (+)-72, (-)-72, (+)-73 and $(-)-73$, respectively. Hydroxamic acids (+)-80 and (-)-80 were synthesized by the hydrogenation of (+)-82 and (-)-82 in Winci autoclave with palladium/charcoal in EtOH (see in details in Experimental section) (Schemes 22 and 23). 


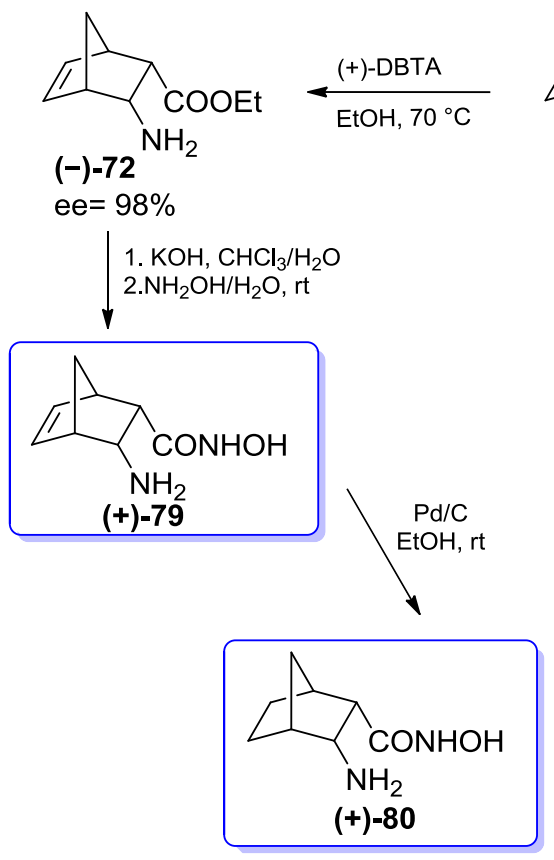

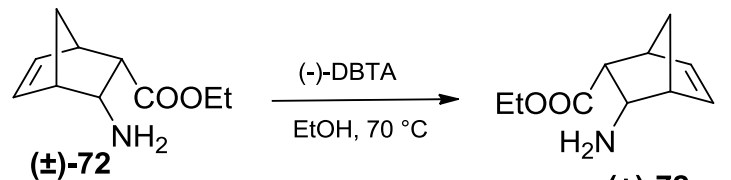

$(+)-72$

ee $=92 \%$

1. $\mathrm{KOH}, \mathrm{CHCl}_{3} / \mathrm{H}_{2} \mathrm{O}$ 2. $\mathrm{NH}_{2} \mathrm{OH} / \mathrm{H}_{2} \mathrm{O}$, rt

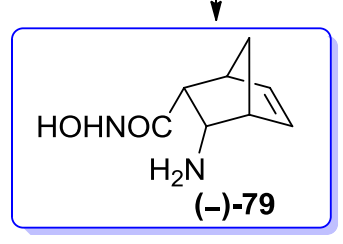

Scheme 22

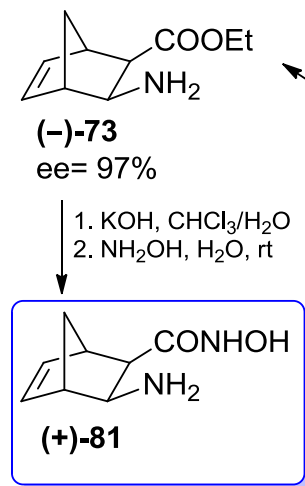

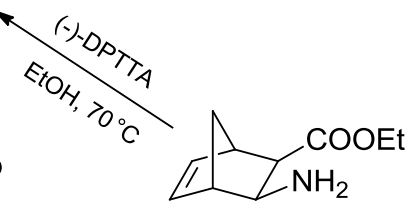

$( \pm)-73$

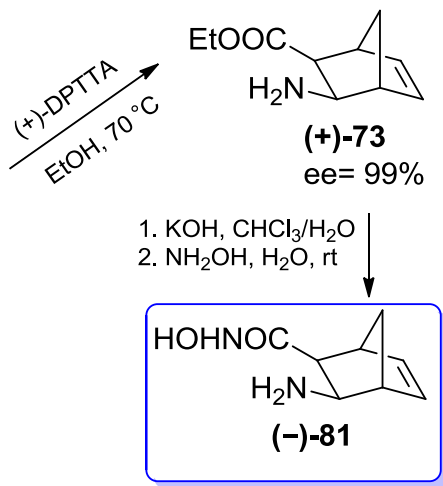

Scheme 23

To determine the absolute configuration, ester base (+)-72 was transformed into urea compound (-)-87 by reacting with $(S)-(-)-\alpha$-methylbenzyl isocyanate $\left(\mathrm{Et}_{2} \mathrm{O}\right.$, ambient temperature) and the resulting crystals were examined by X-ray crystallography. The X-ray structure clearly shows the $1 S, 2 R, 3 S, 4 R$ configuration of the starting (+)-72 base (Figure $11)$.

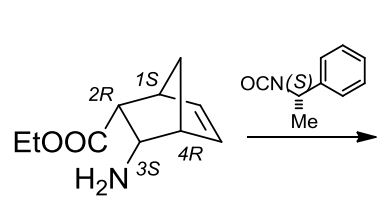

$(+)-72$

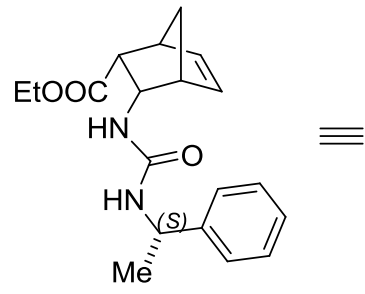

$(-)-87$

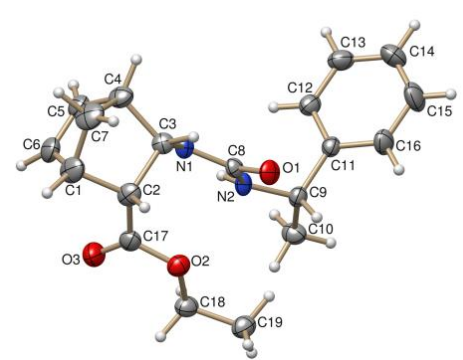

Figure 11 


\section{Resolution of ethyl diexo-3-aminobicyclo[2.2.1]heptane-2-carboxylate ( \pm -74}

Saturated diexo racemic ester $( \pm)-\mathbf{7 4}$ was resolved with (+)-DBTA and (-)-DBTA in EtOH at $70{ }^{\circ} \mathrm{C}$ as described above. Enantiomer excesses were determined by GC equipped with Chromopak Chiralsil-Dex CB column. The absolute configuration of ester (+)-74 was proved by comparing the $[\alpha]_{D}^{20}$ value with literature data. ${ }^{[84]}$ Hydroxamic acids $(-)-82$ and (+)-82 were prepared by treating free ester enantiomers with hydroxylamine solution [I] (Scheme 24, Table 4).

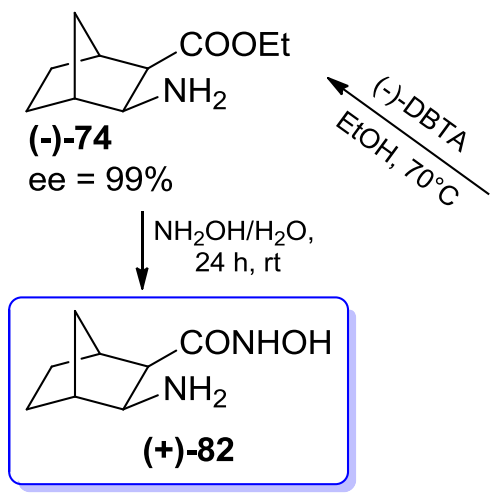

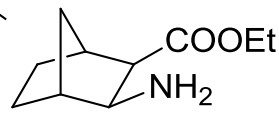

$( \pm)-74$
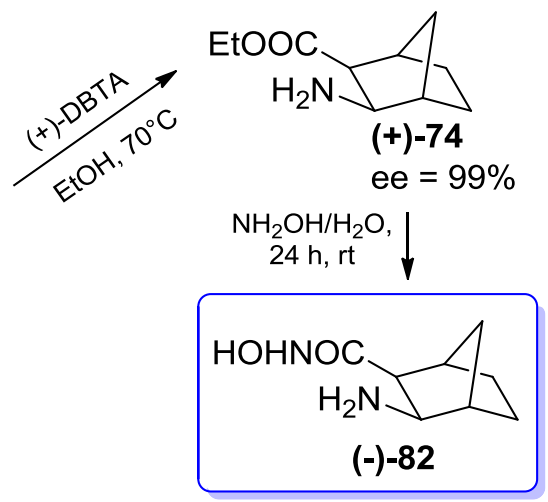

Scheme 24

Table 4. Optical rotation data of ester and 2-aminohydroxamic acid enantiomers

\begin{tabular}{|c|c|c|c|}
\hline $\begin{array}{c}\text { Starting ester } \\
\text { enantiomers } \\
(e e)\end{array}$ & $\begin{array}{l}\text { Optical rotation of ester } \\
\text { enantiomers in EtOH } \\
\text { (literature data) }\end{array}$ & $\begin{array}{c}\text { Structure of } \\
\text { hydroxamic } \\
\text { acid enantiomers }\end{array}$ & $\begin{array}{l}\text { Optical rotation of } \\
\text { hydroxamic acid } \\
\text { enantiomers in } \mathrm{H}_{2} \mathrm{O}\end{array}$ \\
\hline - & - & $\begin{array}{c}\mathrm{CONHC} \\
\mathrm{NH}_{2} \\
(+)-80\end{array}$ & $+25.2, c=0.49$ \\
\hline- & - & $\begin{array}{r}\mathrm{HOHNOC} \mathrm{S}_{\mathrm{S}} \\
\mathrm{H}_{2} \mathrm{~N} \\
(-)-80\end{array}$ & $-26.8, c=0.50$ \\
\hline $\begin{array}{c}(+)-74 \\
99 \%\end{array}$ & $\begin{array}{c}+6.8, \mathrm{c}=1 \\
(\text { antipode: }-6.3, \mathrm{c}=1)^{[84]}\end{array}$ & $\begin{array}{c}\mathrm{HOHNOC} S R / \\
(-)-82\end{array}$ & $-33.7, c=0.49$ \\
\hline $\begin{array}{l}(-)-74 \\
99 \%\end{array}$ & $\begin{array}{c}-4.7, c=1 \\
(-6.3, c=1)^{[84]}\end{array}$ & $\sum_{R} \sum_{S}^{S} \mathrm{NH}_{2} \mathrm{CONHC}_{(+)-82}$ & $+34, \mathrm{c}=0.48$ \\
\hline
\end{tabular}




\section{Enantioseparation of $\beta$-aminohydroxamic acids on chiral zwitterionic stationary phases}

Hydroxamic acids (+)-72, (-)-72, (+)-73, (-)-75, (+)-76, (-)-77, (+)-78, (+)-79, (-)-79, (+)80, (-)-80, (+)-81, (-)-81, (+)-82 and (-)-82 were successfully separated by HPLC [III, IV]. István Ilisz and his co-workers developed a liquid chromatographic method applying Cinchona alkaloid-based zwitterionic chiral stationary phases [Chiralpack ZWIX $(-)^{\mathrm{TM}}$, $\mathrm{ZWIX}(+)^{\mathrm{TM}}$, ZWIX(+A), ZWIX(-A)]. A mixture of $\mathrm{MeOH}$ and $\mathrm{ACN}$ containing acid $(\mathrm{AcOH})$ and base (DEA or TEA) additives was applied as mobile phase. The influence on enatioseparation was examined by varying the water content of the elution mixture, the acid/base ratio and the counter-ion concentration of the mobile phase. The best results were achieved with the mobile phase $\mathrm{MeOH} / \mathrm{ACN}(50: 50)$ and an acid/base ratio of 2:1.

\subsection{Domino reaction of diendo- and diexo-2-aminonorbornene hydroxamic acids with oxocarboxylic acids}

The ring-closure reaction of several norbornene derivatives ${ }^{[86,87]}$ including amides ${ }^{[88]}$ was examined earlier in our institute. The reactions of carboxamides with oxocarboxylic acids (levulinic acid, $\alpha$-ketoglutaric acid, 2-formylbenzoic acid) gave tetra- and pentacyclic compounds with medium to good yields by treatment at reflux temperature in toluene. For the examination of the ring-closure activity and stereoselectivity of alicyclic aminohydroxamic acids, diendo- and diexo-aminonorbornene hydroxamic acids $\mathbf{7 9}$ and $\mathbf{8 1}$ were selected as model compounds.

Reaction mixtures were heated at reflux temperature or using microwave irradiation. The first step of the domino reaction is the formation of Schiff base A from hydroxamic acid and oxocarboxylic acid. Compound $\mathbf{A}$ then undergoes ring closure to produce quinazoline epimers $\mathbf{B}$ and $\mathbf{C}$ through ring-chain tautomerism. The second intramolecular process involves $\mathbf{B}$ and $\mathbf{C}$ yielding lactams $\mathbf{D}$ and $\mathbf{E}$ via the nucleophilic attack of the ring nitrogen. Since a new asymmetric centre was generated in these reactions, two epimers were formed. The relative configuration of the newly-built asymmetric centres is controlled by the stereochemistry of the starting material (Scheme 25). 
$\overbrace{\mathrm{NH}_{2}}^{\mathrm{O}}$

79: diendo

81: diexo

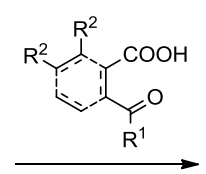<smiles>[R]C(=NC1C2C=CC(C2)C1C(=O)NO)c1ccc([R])c([R])c1C(=O)O</smiles>

A<smiles>[R]c1ccc(C2([R])NC3C4C=CC(C4)C3C(=O)N2O)c(C(=O)O)c1[R]</smiles><smiles>[R]c1ccc(C2([R])NC3C4C=CC(C4)C3C(=O)N2O)c(C(=O)O)c1[R]</smiles><smiles>[R]c1ccc2c(c1[R])C(=O)N1c3ccccc3C(=O)N(O)C21[R]</smiles><smiles>[R]c1ccc2c(c1[R])C(=O)N1C3CCC(CC3)C3C(=O)N(O)C1([R])C23</smiles>

Scheme 25

In preliminary experiment, the ring closure of racemic diendo- and diexo-aminonorbornene hydroxamic acids $( \pm)$-79 and $( \pm)$-81 with oxocarboxylic acid was tested. In the ring closure of diendo- $( \pm)-79$ and diexo- $( \pm)-81$ aminohydroxamic acids with 2-formylbenzoic acid and 6-formyl-2,3-dimethoxybenzoic acid, the formation of single epimers of $( \pm)-\mathbf{8 8}-( \pm)-\mathbf{9 1}$ took place. The domino reaction of levulinic acid and $\alpha$-ketoglutaric acid, in turn, produced two diastereomers of $( \pm)-92-( \pm)-95$. Unfortunately, the diastereomers of $( \pm)-92-( \pm)-95$ could not separated by column chromatography despite the use of a range of eluent combinations [I, II] (Scheme 26).<smiles>[R]c1ccc2c(c1[R])C(=O)N1C3C4C=CC3C1C4C(=O)N2O</smiles>

diendo: ( \pm )-88: $\mathrm{R}^{2}=\mathrm{H}$

$( \pm)-90: R^{2}=O M e$

diexo: (士)-89: $\mathrm{R}^{2}=\mathrm{H}$

(士)-91: $R^{2}=O M e$

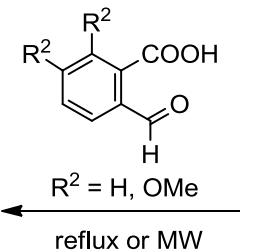

(士)-79: diendo

(士)-81: diexo<smiles>O=C(O)CCC(=O)O</smiles>

diendo: (士)-92: $\mathrm{R}^{1}=\mathrm{Me}$

(士)-94: $\mathrm{R}^{1}=\mathrm{COOH}$

diexo: $(\mathbf{\pm})-93: \mathrm{R}^{1}=\mathrm{Me}$

(士)-95: $\mathrm{R}^{1}=\mathrm{COOH}$

Scheme 26

Fortunately, after treatment with diazomethane, the resulting methoxy derivative of diastereomers $( \pm)-96 \mathbf{a}-( \pm)-99 \mathbf{a}$ and $( \pm)-96 \mathbf{b}-( \pm)-99 \mathbf{b}$ could be easily separated by column chromatography upon elution with EtOAc. The diastereoselectivity of the reactions were detected by TLC and ${ }^{1}$ H-NMR spectroscopy [II] (Scheme 27). 
<smiles>CC12CCC(=O)N1C1C3C=CC(C3)C1C(=O)N2O</smiles>

diendo: ( \pm )-92

diexo: ( $\mathbf{( \pm ) - 9 3}$

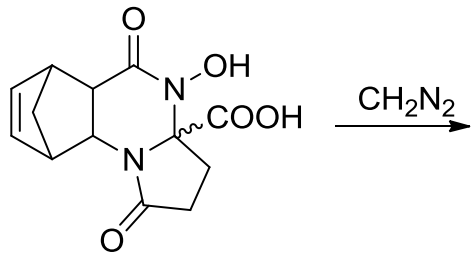

diendo: ( \pm )-94 diexo: ( $\mathbf{(})-95$<smiles>CON1C(=O)C2C3C=CC(C3)C2N2C(=O)CCC12C</smiles>

(士)-96a

$( \pm)-97 a$<smiles>COC(=O)C12CCC(=O)N1C1C3C=CC(C3)C1C(=O)N2OC</smiles>

(士)-98a

(士)-99a<smiles>CON1C(=O)C2C3C=CC(C3)C2N2C(=O)CC[C@]12C</smiles>

(士)-96b $( \pm)-97 b$
$( \pm)-96 a:( \pm)-96 b=5: 2$;
$( \pm)-98 \mathbf{a}:( \pm)-98 \mathbf{b}=5: 4$,
$( \pm)-97 \mathbf{a}:( \pm)-97 \mathbf{b}=2: 5$;
$( \pm)-99 \mathbf{a}:( \pm)-99 \mathbf{b}=5: 4$<smiles>COC(=O)[C@@]12CCC(=O)N1C1C3C=CC(C3)C1C(=O)N2OC</smiles>

Scheme 27

All reactions were repeated with enantiomerically enriched aminohydroxamic acids (+)-79 and (+)-81 (Schemes 28 and 29).

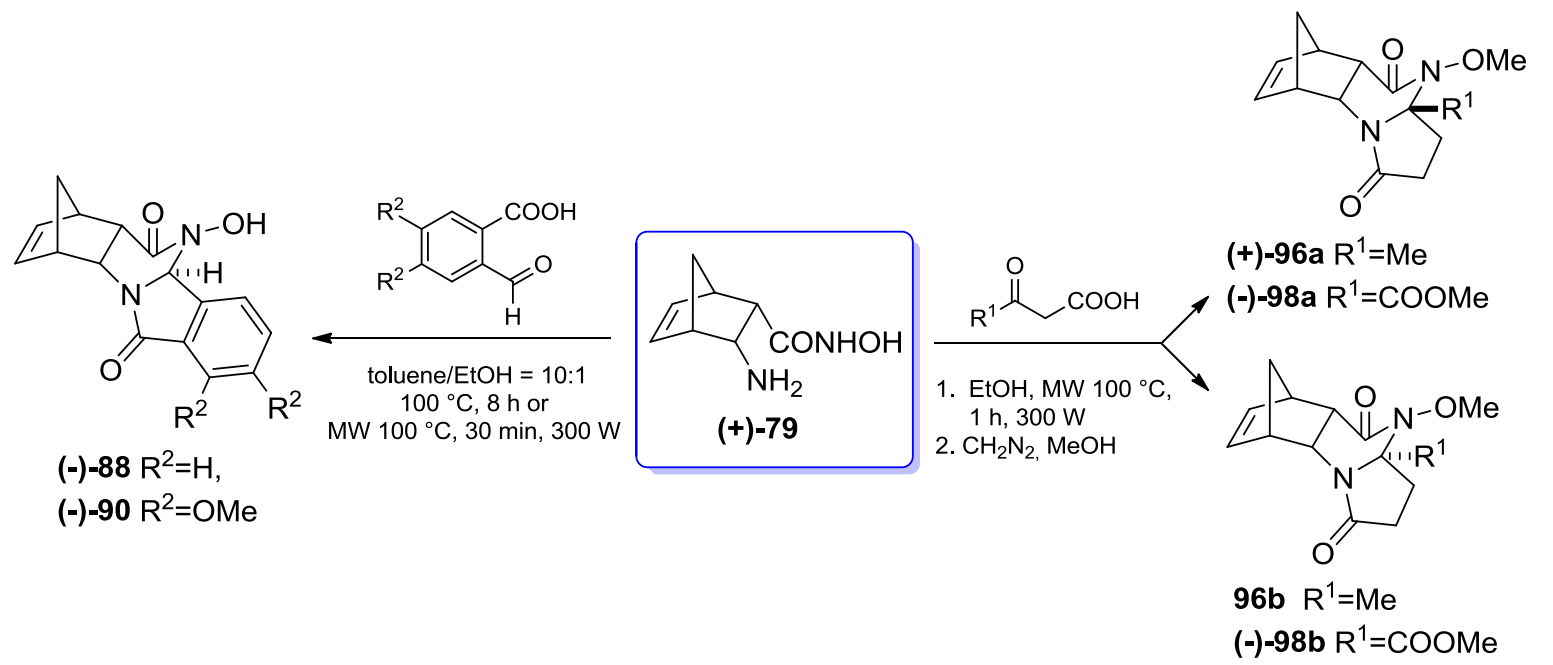

Scheme 28 


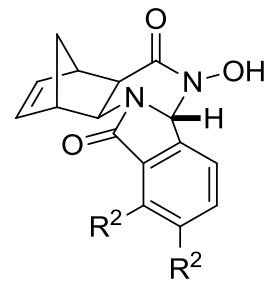

$(+)-89 \mathrm{R}^{2}=\mathrm{H}$

$(+)-91 R^{2}=\mathrm{OMe}$

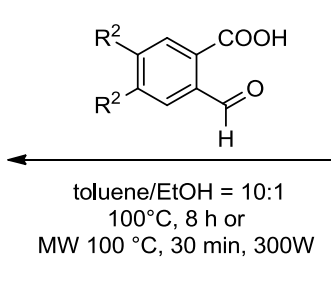

$\mathrm{MW} 100^{\circ} \mathrm{C}, 30 \mathrm{~min}, 300 \mathrm{~W}$

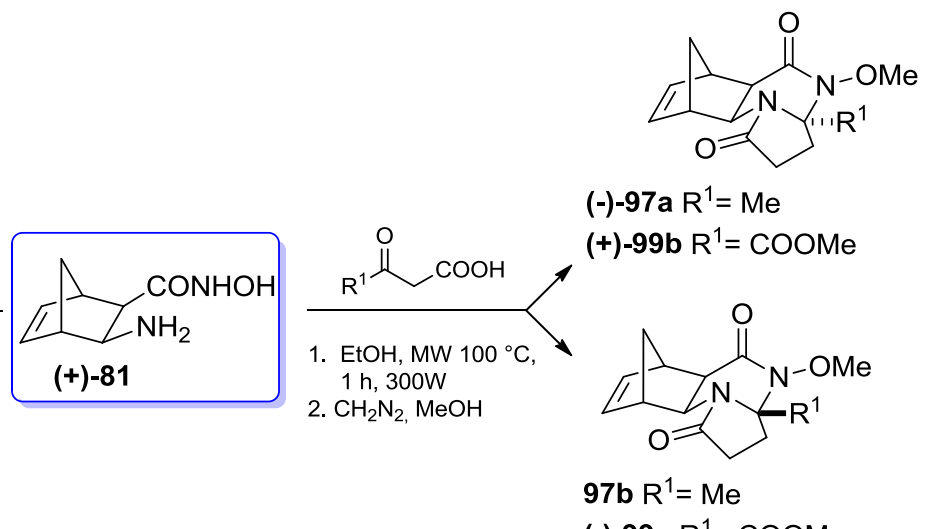

$(-)-99 a R^{1}=$ COOMe

Scheme 29

We compared the diastereoselectivity of domino reactions with 2-formylbenzoic acid and levulinic acid in the case of methyl-substituted diexo-2-aminocarboxamide $( \pm)$-100 and -2aminohydroxamic acid $( \pm)-\mathbf{8 1}$.

The ring-closure reactions of diexo-2-aminocarboxamide $( \pm)$-100, were earlier examined in our institute. ${ }^{[88]}$ The domino ring-closure reactions of diexo amide $( \pm)$-100 with levulinic acid and 2-formylbenzoic acid (reflux in toluene) resulted in single epimers isoindolo[1,2$a$ ]quinazoline $( \pm)$-101 and pyrrolo[1,2-a]quinazoline ( \pm -102 with good yields. The relative configurations of the new asymmetric centre of products $( \pm)-\mathbf{1 0 1}$ and $( \pm)-\mathbf{1 0 2}$ were different $^{[88 \mathrm{a}]}$ (Scheme 30).

In the case of the ring closure of diexo hydroxamic acid $( \pm)-81$ performed under similar reaction conditions, products isoindolo[1,2-a]quinazoline $( \pm)-89$ and pyrrolo[1,2a]quinazoline ( \pm -93a had the same relative configuration as before, but a small amount of the minor epimer of pyrrolo[1,2-a]quinazoline ( \pm )-93b was also formed.

We assume, that the diastereoselectivity, in one hand, may due to the high rigidity of norbornene skeleton and, on the other hand, to the steric effect of the $\mathrm{N}-\mathrm{R}$ groups. Namely, the $\mathrm{N}-\mathrm{Me}$ group is considered to be more spacious than the $\mathrm{N}-\mathrm{OH}$ group (Scheme 31 ). 


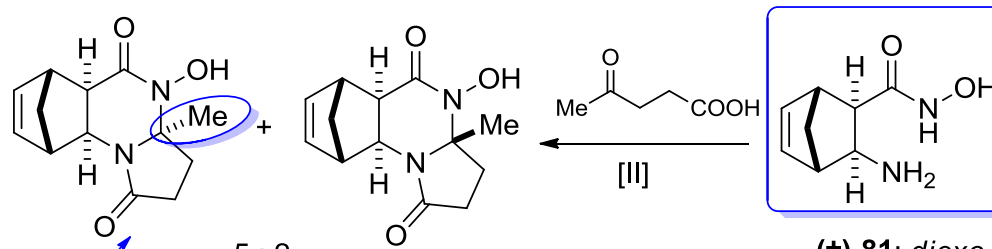

$5: 2$

(士)-93a,b

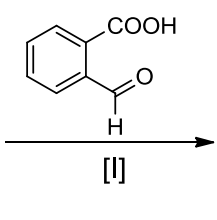

(士)-81: diexo

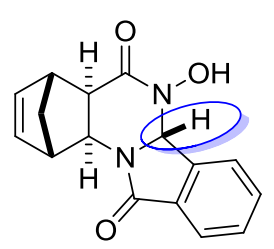

(士)-89

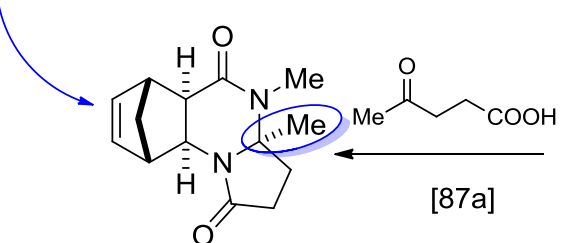

(土)-102

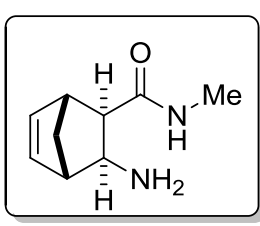

(士)-100: diexo

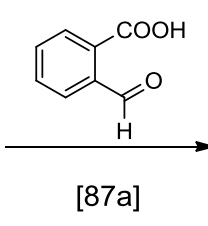

87a]

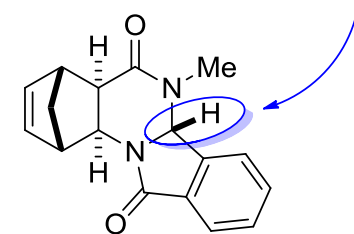

(士)-101

Scheme 30

Structure elucidation of domino products by X-ray diffraction analysis and/or 2D-NMR spectroscopy

The relative stereochemistry of the domino products were elucidated via 2D-NMR spectroscopy depending on NOE (nuclear Overhauser effect). One of the nuclear spins shows changes in the intensity of its NMR signal. Resonance line changes caused by dipolar cross relaxation from neighbouring spins. NOESY measurements reveal couplings between hydrogen atoms separated in space by a distance less than $5 \AA$ and provide useful information in determining stereochemistry. ${ }^{[89]}$

The characteristic NOE cross-peaks in ( \pm )-88 and $( \pm)-\mathbf{9 0}$ revealed that the relative configuration of the hydrogen of the newly-formed asymmetric centre and the annelated hydrogen atoms are trans. Characteristic structure cross-peaks were found between the $\mathrm{C}(6 \mathrm{a})-H$ and $\mathrm{C}(2)-H$ protons $(6.32-5.85,6.34-5.85$ and $6.30-5.71,6.43-5.71)$. The hydrogen of the new asymmetric centre and the hydrogen atoms of the methylene bridge are on the same side in $( \pm)-89$ and $( \pm)$-91. Characteristic structure cross-peaks are between protons C(6a)-H and C(13)-H (1.68-6.04 and 1.66-5.94) (Figure 13). 


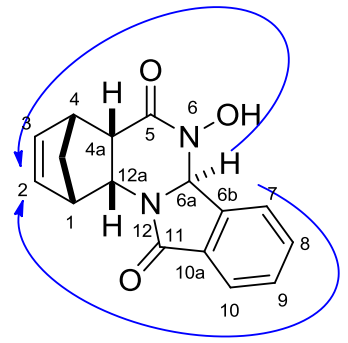

$( \pm)-88$

NOE: $6.32-5.85$ 6.34-5.85

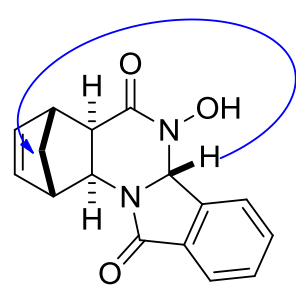

$( \pm)-89$

NOE: $1.68-6.04$

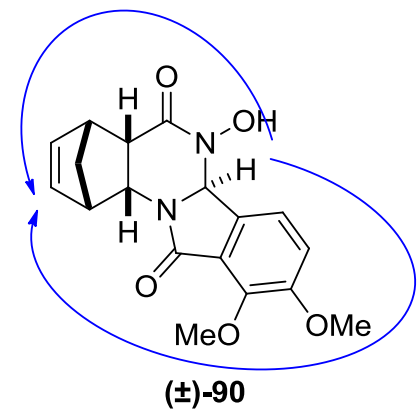

NOE: $6.30-5.71$

6.43-5.71

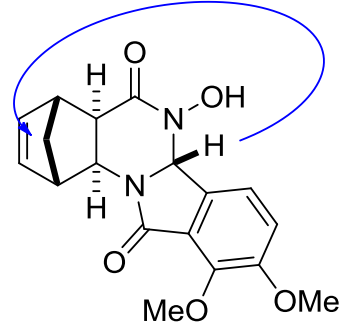

$(\mathbf{\pm}-\mathbf{- 9 1}$

NOE: $166-5.94$

Figure 13

The stereochemistry of $( \pm)$-88 was confirmed by single-crystal X-ray analysis as well and the result is in agreement with the NOESY measurements (Figure 14).<smiles>O=C1C(=O)N(O)[C@H]2[C@@H]1[C@@H]1C=C[C@H]2C1</smiles>

$( \pm)-88$<smiles>C#CC1CC2CC1C1C(=O)N2C(=O)C1C(=O)NO</smiles>
$\mathrm{HO}$

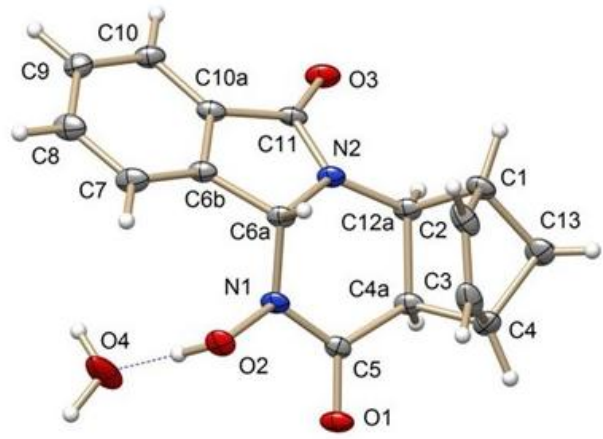

Figure 14

The relative configuration of $( \pm)-96 a,( \pm)-98 a$ and $( \pm)-99 b$ were proved via X-ray diffraction measurements. Crystals of $( \pm)$-96a, $( \pm)$-98a and $( \pm)-99 \mathbf{b}$ were immersed in cryoil, mounted in a MiTeGen loop and measured at $120 \mathrm{~K}$ (Figure 15-17).<smiles>C#CC1(C)CCC(=O)N1[C@H]1[C@@H]2C=C[C@@H](C2)[C@H]1C(=O)NC</smiles>

$( \pm)-96 a$

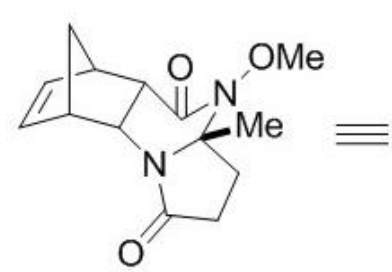

Figure 15

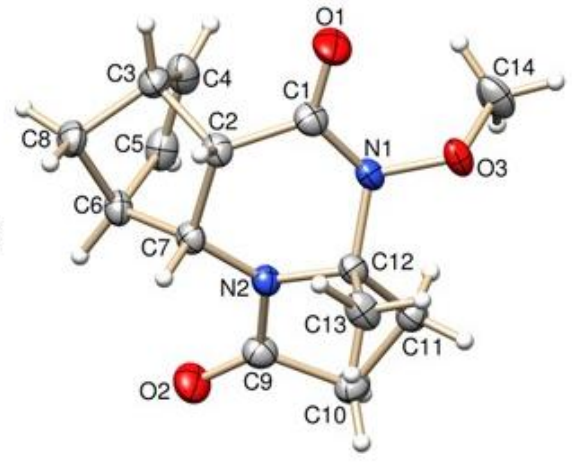




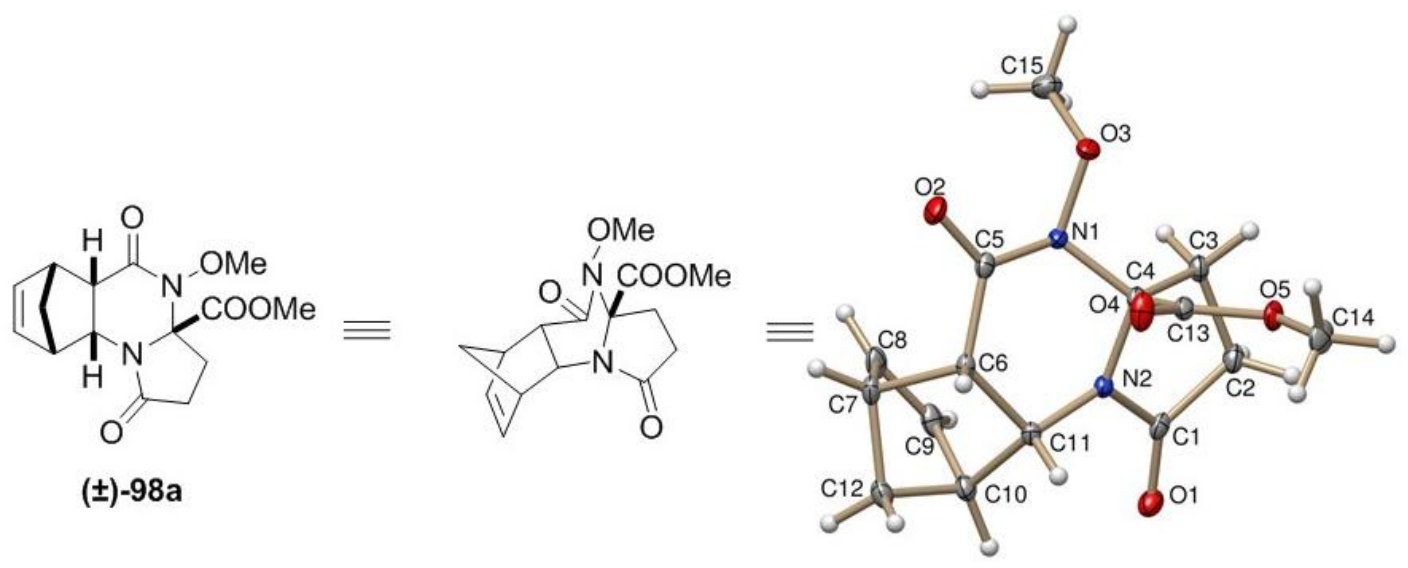

Figure 16

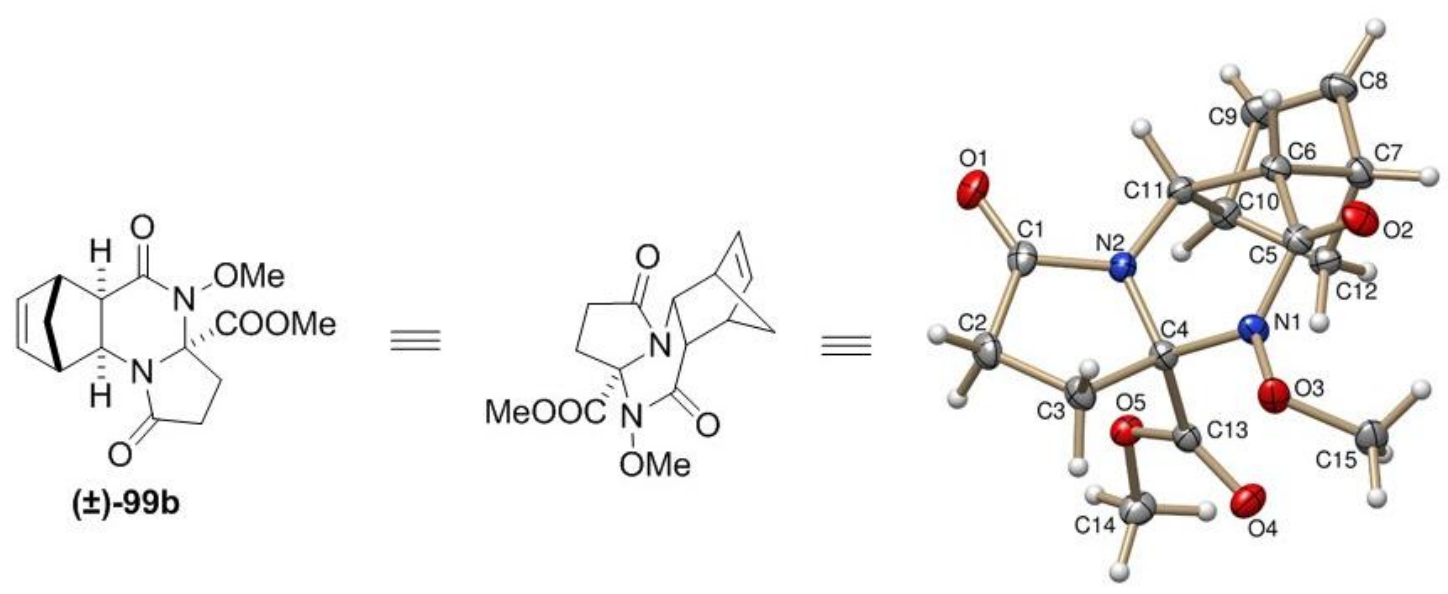

Figure 17

\section{Structure elucidation of (+)-97a and (-)-97a}

The absolute configuration of the newly-built asymmetric centre of (+)-97a was determined by chemical correlation: the absolute configuration of the starting 2aminonorbornene hydroxamic acid (-)-81 and the relative configuration of $( \pm)$-96a from the X-ray diffraction analysis were known (Scheme 31). When (+)-96a was heated under the RDA reaction conditions, (-)-116 was formed. In addition, the RDA reaction of (+)97a also afforded (-)-116. In contrast, when (-)-96a and (-)-97a were treated under the RDA reaction conditions, (+)-116 was formed. The ${ }^{1} \mathrm{H}$ NMR and HPLC data (retention times: (-)-116: $41.91 \mathrm{~min}$, opposite enantiomer (+)-116: $34.19 \mathrm{~min})$ and comparison of the optical rotations revealed that the final compound was identical to that of $(R)$-1-methoxy8a-methyl-1,7,8,8a-tetrahydropyrrolo[1,2-a]pyrimidine-2,6-dione ((-)-116). Since this asymmetric centre was not affected during the RDA reaction, these results allow for the assumption that the absolute configuration of position 3a of (+)-97a is $R$, and that of (-)97a is $S$ 


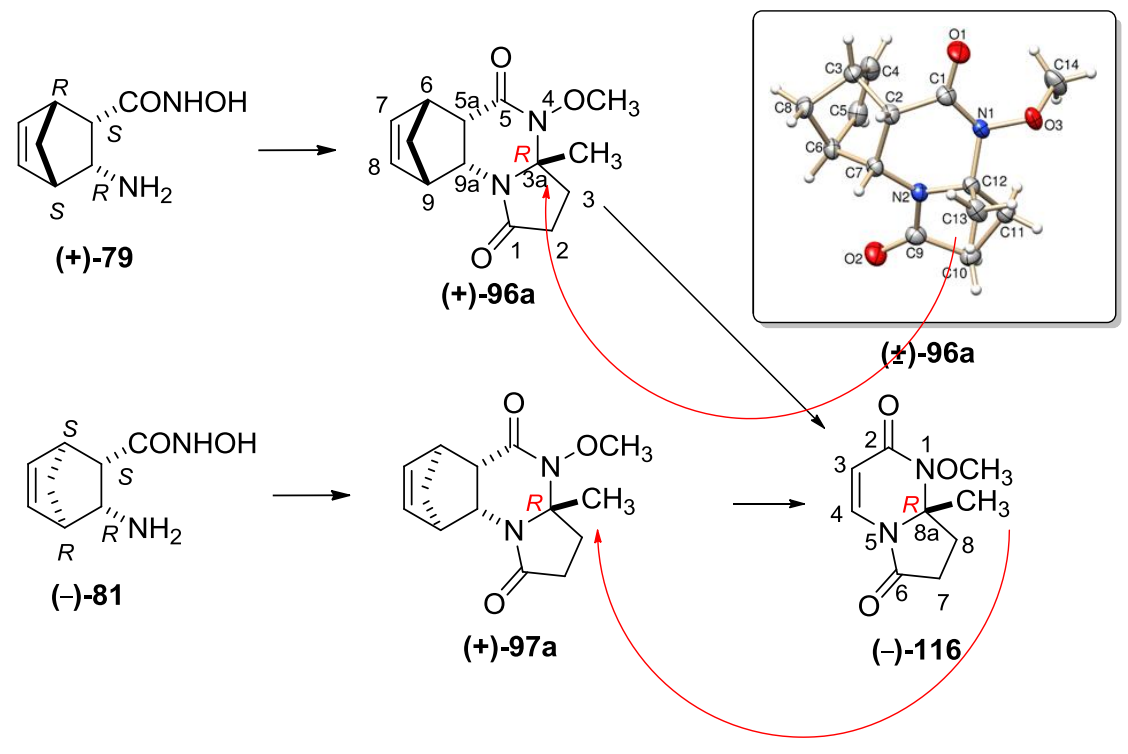

Scheme 31

\subsection{Retro Diels-Alder reactions of isoindolo[2,1-a]quinazolines and pyrrolo- [1,2-a]quinazolines}

A simple, medium-yielding synthetic pathway has been designed to create complex structures, using domino followed by retro Diels-Alder (RDA) reactions through a traceless chirality transfer strategy. During the first step of our synthesis route, the high rigidity of the norbornene skeleton facilitates the efficient transfer of the stereochemical information to the newly-formed stereogenic centre of isoindolo[2,1-a]quinazolinones $((-)-88,(+)-89,(-)-90,(+)-91)$ and pyrrolo[1,2-a]quinazolines ((+)-96a, (-)-97a, (-)-98a, $(-)-98 b,(-)-99 a,(+)-99 b)$. The configuration is not affected during the subsequent step (RDA reaction), which allowed to define the absolute configuration of the final products. First, the RDA step was implemented and optimized with racemic compounds followed by repeating the reactions with the enantiomers. Note that all spectroscopic data of the racemic compounds were identical to those of the enantiomeric samples. In Schemes 31 and 32 only a single enantiomer is depicted for clarity.

Various conditions for the RDA reaction of domino products were applied such as heating the molten phase or treatment under microwave irradiation in different solvents (toluene, DMF, dioxane or DCB), but conversions were not complete. Furthermore, in each case, a range of decomposition products appeared in the reaction mixture (detected by TLC) and the desired products could be separated only in small quantities.

Pentacyclic compounds (-)-88, (+)-89, (-)-90 and (+)-91 were transformed to $O$-methyl and $O$-benzyl derivatives (Scheme 32). For the synthesis of $O$-methyl derivatives, domino 
products (-)-88, (+)-89, (-)-90 and (+)-91 were dissolved in EtOH and stirred at room temperature or at $-10{ }^{\circ} \mathrm{C}$. Next, a solution of diazomethane in $\mathrm{Et}_{2} \mathrm{O}$ was added dropwise and the reaction mixture was stirred for 20-30 min until no starting material could be observed by TLC. (Caution: diazomethane is a very harmful and hazardous reagent and must be handled with care. This reaction should be performed in well-ventilated hood.) The solvent was then removed by evaporation and the residue was dissolved in EtOAc and transferred to silica gel column and eluted with EtOAc. Methoxy products (-)-103, (-)104, (+)-107 and (+)-108 were crystallized from $i \operatorname{Pr}_{2} \mathrm{O}$ to afford white crystals. For the synthesis of the benzyloxy derivatives, isoindolo[2,1-a]quinazolines (-)-88, (+)-89, (-)-90 and (+)-91 were dissolved in anhydrous THF and then NaH in THF was added dropwise. The reaction mixture was stirred for $2 \mathrm{~h}$ at $0{ }^{\circ} \mathrm{C}$ then, after adding benzyl bromide, stirring was continued for $1 \mathrm{~h}$ at room temperature. A few drops of water were added to the reaction mixture to decompose excess $\mathrm{NaH}$. After completion, the solvent was evaporated and water was added to the residue, which was extracted with chloroform. The crude products were dissolved in EtOAc and transferred to silica gel column and were eluted with EtOAc. Benzyloxy derivatives (+)-105, (+)-106, $(-)-\mathbf{1 0 9}$ and $(-)-\mathbf{1 1 0}$ were obtained as white crystals.

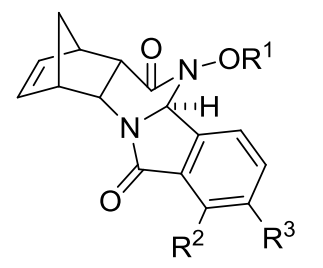

$(+)-105 R^{1}=B n, R^{2}=R^{3}=H$,

$(+)-106 R^{1}=B n, R^{2}=R^{3}=\mathrm{OMe}$
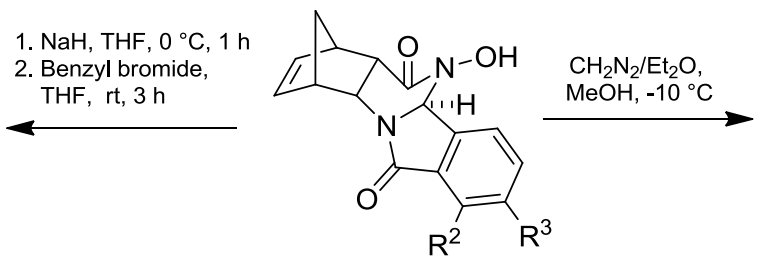

$(-)-88 R^{2}=R^{3}=H$,

$(-)-90 R^{2}=R^{3}=O M e$

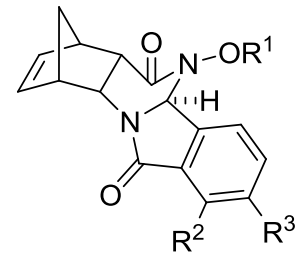

$(-)-103 R^{1}=M e, R^{2}=R^{3}=H$,

$(-)-104 R^{1}=M e, R^{2}=R^{3}=O M e$<smiles>[R]c1ccc2c(c1[R])c(=O)n(C1CC1)c(=O)n2OCC</smiles>

(-)-109 $R^{1}=B n, R^{2}=R^{3}=H$

$(-)-110 R^{1}=B n, R^{2}=R^{3}=O M e$

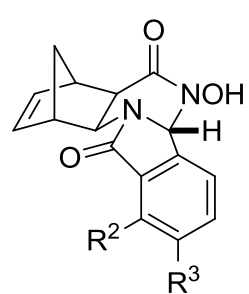

$(+)-89 R^{2}=R^{3}=H$

$(+)-91 R^{2}=R^{3}=\mathrm{OMe}$

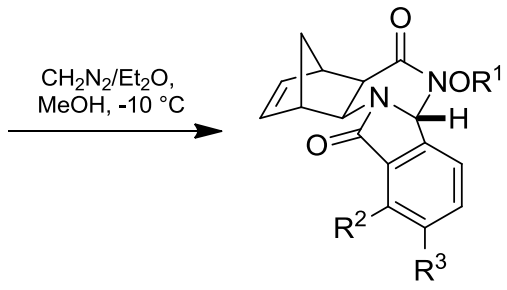

$(+)-107, R^{1}=M e, R^{2}=R^{3}=H$

$(+)-108 R^{1}=\mathrm{Me}, \mathrm{R}^{2}=\mathrm{R}^{3}=\mathrm{OMe}$

Scheme 32

The methoxy and benzyloxy derivatives have lower melting points, they are more hydrophobic, their RDA reactions occurred more easily and the expected compounds could 
be more easily isolated from the crude products. Cycloreversion of tetracyclic $\mathrm{MeO}$ esters could also be easily achieved.

Tetra- or pentacyclic compounds (+)-96a, (-)-97a, (-)-98a, (-)-98b, (-)-99a, (+)-99b, (-)103, (-)-104, (+)-105, (+)-106, (+)-107, (+)-108, (-)-109 and (-)-110 were dissolved in DCB and stirred for $20 \mathrm{~min}$ at $160-240{ }^{\circ} \mathrm{C}$ under microwave irradiation (max. $300 \mathrm{~W}$ ). Then the solvent was evaporated and the residue was dissolved in EtOAc and purified by column chromatography on silica gel eluting with EtOAc or EtOAc/hexane (2:1). After evaporation, white crystals were produced or the products were crystallized from $i \operatorname{Pr}_{2} \mathrm{O}$. During the reactions no epimerisation or racemisation were observed and the stereochemical information were effectively transferred to the products, demonstrating that the starting compounds are excellent chiral sources (Scheme 33, Table 5).

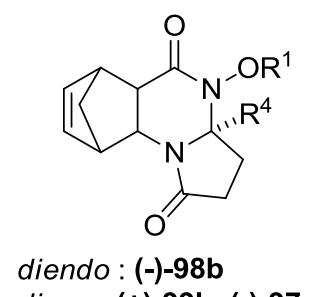

diexo: $(+)-99 b,(-)-97 a$

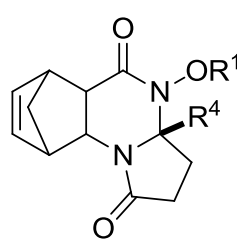

diendo : (+)-96a, (-)-98a diexo: (-)-99a

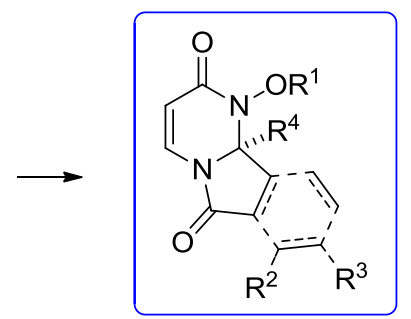

$(+)-111,(+)-112,(+)-113$, $(+)-114(+)-115,(+)-116$

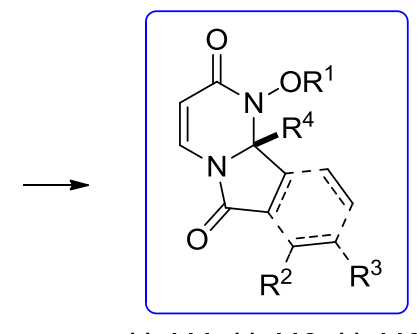

$(-)-111,(-)-112,(-)-113$, $(-)-114(-)-115,(-)-116$

Scheme 33

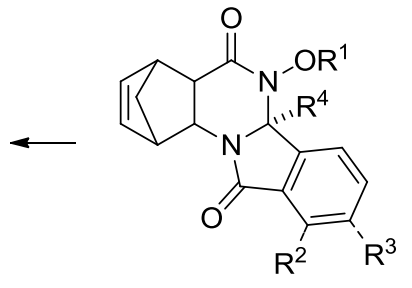

diendo : (-)-103, (-)-104,

(+)-105, (+)-106

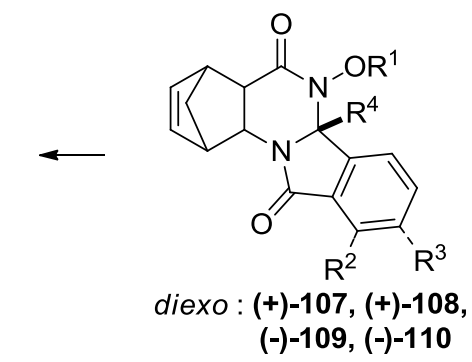


Table 5. Substituents of the pyrimido[2,1-a]isoindole 111-114 and pyrrolo[1,2-a]pyrimidine $\mathbf{1 1 5}$ and $\mathbf{1 1 6}$ derivatives

\begin{tabular}{cccccc}
\hline & $\mathrm{R}^{1}$ & $\mathrm{R}^{2}=\mathrm{R}^{3}$ & $\mathrm{R}^{4}$ & $e e \%$ & Yield \% \\
\hline \hline$(+)-\mathbf{1 1 1}$ & $\mathrm{Me}$ & $\mathrm{H}$ & $\mathrm{H}$ & 95 & 27 \\
\hline$(-)-\mathbf{1 1 1}$ & $\mathrm{Me}$ & $\mathrm{H}$ & $\mathrm{H}$ & 99 & 29 \\
\hline$(+)-\mathbf{1 1 2}$ & $\mathrm{Me}$ & $\mathrm{MeO}$ & $\mathrm{H}$ & 98 & 31 \\
\hline$(-)-\mathbf{1 1 2}$ & $\mathrm{Me}$ & $\mathrm{MeO}$ & $\mathrm{H}$ & 97 & 37 \\
\hline$(+)-\mathbf{1 1 3}$ & $\mathrm{Bn}$ & $\mathrm{H}$ & $\mathrm{H}$ & 95 & 36 \\
\hline$(-)-\mathbf{1 1 3}$ & $\mathrm{Bn}$ & $\mathrm{H}$ & $\mathrm{H}$ & 99 & 32 \\
\hline$(+)-\mathbf{1 1 4}$ & $\mathrm{Bn}$ & $\mathrm{MeO}$ & $\mathrm{H}$ & 93 & 54 \\
\hline$(-)-\mathbf{1 1 4}$ & $\mathrm{Bn}$ & $\mathrm{MeO}$ & $\mathrm{H}$ & 99 & 41 \\
\hline$(+)-\mathbf{1 1 5}$ & $\mathrm{Me}$ & - & $\mathrm{COOMe}$ & 95 & 57 \\
\hline$(-)-\mathbf{1 1 5}$ & $\mathrm{Me}$ & - & $\mathrm{COOMe}$ & 99 & 59 \\
\hline$(+)-\mathbf{1 1 6}$ & $\mathrm{Me}$ & - & $\mathrm{Me}$ & 99 & 99 \\
\hline$(-)-\mathbf{1 1 6}$ & $\mathrm{Me}$ & - & $\mathrm{Me}$ & 99 & 29 \\
\hline
\end{tabular}




\section{EXPERIMENTAL}

\section{General procedures}

${ }^{1} \mathrm{H}-\mathrm{NMR}$ spectra were recorded at $400.13 \mathrm{MHz}$ or $600.20 \mathrm{MHz}$ and the ${ }^{13} \mathrm{C}-\mathrm{NMR}$ spectra were recorded at $100.62 \mathrm{MHz}$ or $150.92 \mathrm{MHz}$ in $\mathrm{CDCl}_{3}$ or in $\left[\mathrm{D}_{6}\right] \mathrm{DMSO}$ at ambient temperature, with a Bruker AM 400 or Bruker AV 600 spectrometer (Bruker Biospin, Karlsruhe, Germany). Chemical shifts are given in $\delta(\mathrm{ppm})$ relative to TMS as internal standard. Microwave-promoted reactions were performed in sealed reaction vials $(10 \mathrm{~mL})$ in a microwave (CEM, Discover SP) cavity (CEM Corporation, Matthwes, NC, USA). Optical rotations were measured with a Perkin-Elmer 341 polarimeter (Perkin Elmer, Shelton, CT, USA). Mass spectra were recorded with a Finnigan MAT 95S or Micromass Q-TOF Premier mass spectrometer (Waters Corporation, Milford, MA, USA). Melting points were measured with a Hinotek-X4 micro melting point apparatus (Hinotek, Ningbo, China) and are uncorrected.

HPLC analysis of ethyl (1R,6S)-6-aminocyclohex-3-enecarboxylate ((-)-68) and ethyl (1R,6R)-6-benzamidocyclohex-3-enecarboxylate ((-)-70)

Ethyl $(1 R, 6 S)$-6-benzamidocyclohex-3-enecarboxylate ((-)-68): Phenomenex IA, $n$ hexane/isopropyl alcohol $=90 / 10$; flow rate $1.0 \mathrm{~mL} / \mathrm{min}$; detection at $254 \mathrm{~nm}$; retention time (min): 21.49 (antipode: 18.06). Ethyl (1R,6R)-6-benzamidocyclohex-3-enecarboxylate ((-)-70): Chiracel ODH, $n$-hexane/isopropyl alcohol $=70 / 30$; flow rate $0.7 \mathrm{~mL} / \mathrm{min}$; detection at $254 \mathrm{~nm}$; retention time $(\mathrm{min}$ ): 6.15 (antipode: 7.05), after derivatisation with benzoyl chloride. The free aminoesters were dissolved in DCM and were treated with benzoyl chloride in the presence of TEA at room temperature for 30 minutes. After the reaction mixtures were evaporated to dryness, $N$-benzoyl esters were purified by column chromatography on silica gel column eluting by $n$-hexane/EtOAc $(4: 1)$. The pure samples were combined, evaporated under vacuum and dissolved in HPLC-grade eluent mixtures.

\section{Hydrogenation of (-)-68 and (-)-70 in H-cube ${ }^{T M}$}

Ethyl 6-aminocyclohex-3-enecarboxylate enantiomers ((-)-68, (-)-70) were transformed into ethyl 2-aminocyclohexanecarboxylate enantiomers ((-)-69, (-)-71) with $\mathrm{H}_{2}$ in the presence of $\mathrm{Pd} / \mathrm{C}$. Continuous-flow hydrogenations were carried out in a ThalesNano $\mathrm{H}$ cube $^{\mathrm{TM}}$ system. For each run, $150 \mathrm{mg}$ of catalyst $(\mathrm{Pd} / \mathrm{C})$ was charged into a tubular catalyst cartridge with an inner diameter of $4 \mathrm{~mm}$ and a length of $30 \mathrm{~mm}$. The catalyst was treated 
with a flow of EtOH $\left(1 \mathrm{~mL} \mathrm{~min}^{-1}\right)$ for $0.5 \mathrm{~h}$ followed by pretreatment with $\mathrm{H}_{2}$ for $0.5 \mathrm{~h}$ with the same solvent. Reactants (-)-68 and (-)-70 were dissolved in EtOH and this solution was delivered to the hydrogenation system via a conventional HPLC pump, through the mixer of the apparatus, where $\mathrm{H}_{2}$ was mixed into the liquid flow under a pressure of $1 \mathrm{MPa}$. The catalyst cartridge holder was equipped with an externally controlled cooling jacket. The mixture was pumped through the catalyst bed so as to obtain an ascending flow of the reaction components. Optical rotations of saturated amino ester enantiomers (-)-69 and (-)-71 were measured with a Perkin-Elmer 341 polarimeter and compared with known literature values. The enantiomeric amino ester bases were then reacted with hydroxylamine solution by the above method, affording hydroxamic acid enantiomers (+)-76 and (+)-78. The stereochemistry of the synthesized compounds was determined by ${ }^{1} \mathrm{H}$ NMR spectroscopy.

Synthesis of (1R,2S,3R,4S)-3-amino-N-hydroxybicyclo[2.2.1]heptane carboxamide ((+)80) and (1S,2R,3S,4R)-3-amino-N-hydroxybicyclo[2.2.1]heptane carboxamide ((-)-80) by hydrogenation of hydroxamic acid enantiomers (+)-79 and (-)-79

Hydroxamic acids (+)-79 and (-)-79 (500 mg) were dissolved in EtOH (100 ml) in Winci autoclave at $60{ }^{\circ} \mathrm{C}$ and 50 bar. Palladium on activated carbon (5 wt \%, $120 \mathrm{mg}$ ) was suspended in EtOH and was added to the solution of hydroxamic acids. The reaction mixtures were stirred under 50 bar pressure for 12 hours in $\mathrm{H}_{2}$ atmosphere. The catalyst was filtered off and the reaction mixtures were evaporated to dryness. The crude products were crystallized from $\mathrm{Et}_{2} \mathrm{O}$ and recrystallized from EtOAc. Final products (+)-80 and (-)80 were obtained as white crystals.

\section{${ }^{1} \mathrm{H}$ NMR, melting points and optical rotations of the new alicyclic 2-aminohydroxamic acids}

(1R,6S)-6-amino-N-hydroxycyclohex-3-enecarboxamide ((-)-75): m.p.: $145-150{ }^{\circ} \mathrm{C}$, $[\alpha]_{D}^{20}=-13\left(\mathrm{c}=0.50, \mathrm{H}_{2} \mathrm{O}\right),{ }^{1} \mathrm{H}-\mathrm{NMR}\left(400 \mathrm{MHz}\right.$, DMSO, $\left.30{ }^{\circ} \mathrm{C}\right): 1.91-2.37(\mathrm{~m}, 5 \mathrm{H}, \mathrm{H}-1$, $\mathrm{CH}_{2}, \mathrm{CH}_{2}$ ), 3.15-3.18 (m, 1H, H-6), 5.50-5.64 (m, 2H, H-3, H-4)

(1R,2S)-2-amino-N-hydroxycyclohexanecarboxamide ((+)-76): m.p.: $149-154^{\circ} \mathrm{C},[\alpha]_{D}^{20}=$ $+10\left(\mathrm{c}=0.50, \mathrm{H}_{2} \mathrm{O}\right),{ }^{1} \mathrm{H}-\mathrm{NMR}\left(400 \mathrm{MHz}, \mathrm{D}_{2} \mathrm{O}, 30^{\circ} \mathrm{C}\right): 1.55-1.62\left(\mathrm{~m}, 3 \mathrm{H}, \mathrm{CH}_{2}, \mathrm{CH}_{2}\right)$, 1.74-1.79 (m, 1H, $\left.\mathrm{CH}_{2}\right), 2.13-2.15\left(\mathrm{~m}, 3 \mathrm{H}, \mathrm{H}-1, \mathrm{CH}_{2}\right)$ 2.26-2.42 (m, 2H, $\left.\mathrm{CH}_{2}\right) 3.48-3.50$ (m, 1H, H-2) 
(1R,6R)-6-amino-N-hydroxycyclohex-3-enecarboxamide ((-)-77): m.p.: 192-196 ${ }^{\circ} \mathrm{C}$, $[\alpha]_{D}^{20}=-42\left(\mathrm{c}=0.50, \mathrm{H}_{2} \mathrm{O}\right),{ }^{1} \mathrm{H}-\mathrm{NMR}\left(400 \mathrm{MHz}, \mathrm{DMSO}, 30{ }^{\circ} \mathrm{C}\right): 1.96-2.54(\mathrm{~m}, 5 \mathrm{H}, \mathrm{H}-1$, $\mathrm{CH}_{2}, \mathrm{CH}_{2}$ ), 3.27-3.38 (m, 1H, H-6), 5.50-5.60 (m, 2H, H-3, H-4)

(1R,2R)-2-amino-N-hydroxycyclohexanecarboxamide ((+)-78): m.p.: 188-192 ${ }^{\circ} \mathrm{C},[\alpha]_{D}^{20}$ $=+36\left(\mathrm{c}=0.50, \mathrm{H}_{2} \mathrm{O}\right),{ }^{1} \mathrm{H}-\mathrm{NMR}\left(400 \mathrm{MHz}, \mathrm{D}_{2} \mathrm{O}, 30^{\circ} \mathrm{C}\right): 1.52-1.60\left(\mathrm{~m}, 3 \mathrm{H}, \mathrm{CH}_{2}, \mathrm{CH}_{2}\right)$, 1.72-1.76 (m, 1H, $\left.\mathrm{CH}_{2}\right), 2.03-2.13\left(\mathrm{~m}, 3 \mathrm{H}, \mathrm{H}-1, \mathrm{CH}_{2}\right)$ 2.25-2.32 (m, 2H, $\left.\mathrm{CH}_{2}\right) 3.33-3.40$ $(\mathrm{m}, 1 \mathrm{H}, \mathrm{H}-2)$

(1S,2R,3S,4R)-3-amino-N-hydroxybicyclo[2.2.1]heptane carboxamide ((-)-80): $[\alpha]_{D}^{20}=$ -26.8 (c = 0.50, $\left.\mathrm{H}_{2} \mathrm{O}\right)\left({ }^{1} \mathrm{H}-\mathrm{NMR}\left(400 \mathrm{MHz}, \mathrm{DMSO}, 30{ }^{\circ} \mathrm{C}\right): 1.18-1.46(\mathrm{~m}, 1 \mathrm{H}, \mathrm{H}-7), 1.38\right.$ 1.41 (m, 1H, H-7), 1.62-1.68 (m, 1H, H-2), 2.46-2.60 (m, 1H, H-4), 2.81-3.00 (m, 1H, H3), 3.66-3.72 (m, 1H, H-1)

(1S,2R,3S,4R)-3-amino-N-hydroxybicyclo[2.2.1]heptane carboxamide ((-)-82): m.p.: $194-198{ }^{\circ} \mathrm{C}[\alpha]_{D}^{20}=-33.7\left({ }^{1} \mathrm{H}-\mathrm{NMR}\left(400 \mathrm{MHz}, \mathrm{DMSO}, 30{ }^{\circ} \mathrm{C}\right): 1.16-1.22(\mathrm{~m}, 1 \mathrm{H}, \mathrm{H}-7)\right.$, 1.26-1.28 (m, 1H, H-7), 1.45-1.70 (m, 1H, H-2), 1.90-1.96 (m, 1H, H-2) 2.23-2.30 (m, 1H, H-3), 2.35-2.44 (m, 1H, H-4), 3.29-3.31 (d, 1H, H-1, J = 8.3 Hz) 


\section{SUMMARY}

Simple and efficient routes have been developed for the preparation of new racemic and enantiomeric cis- and trans-cyclohexene-, cyclohexane- diendo- and diexonorbornene- and norbornane- $\beta$-aminohydroxamic acids. Racemic 2-aminohydroxamic acids $( \pm)-\mathbf{7 5}-( \pm)$-82 were successfully synthesized starting from appropriate esters $( \pm)$-68$( \pm)$-74 or lactams $( \pm)-83-( \pm)-86$ upon treatment with 3 equiv. of commercial available 50 $\mathrm{wt} \%$ aqueous hydroxylamine solution at room temperature. Optically enriched hydroxamic acids (-)-75, (+)-76, (-)-77, (+)-78, (+)-79, (-)-79, (+)-81, (-)-81, (+)-82 and (-)-82 were successfully prepared as well by the synthetic methods mentioned above starting from enantiomeric amino esters.

The starting amino ester enantiomers were synthesized from racemic esters by resolution via diastereomeric salt formation with commercially available resolution agents (mandelic acid, DBTA, DPTTA). The absolute configuration of ester enantiomers (-)-68, $(-)-69,(-)-70,(-)-71,(+)-74$ and (-)-74 was determined via comparing the measured optical rotations with literature data. For determination of the absolute configuration, ester base (+)-72 was transformed into urea compound $(-)-87$ by reacting with $(S)-(-)-\alpha-$ methylbenzyl isocyanate and the crystalline product was examined by X-ray crystallography. The $e e$ values of the ester enantiomers were determined via HPLC and GC measurements. The diastereomeric salts were liberated to free ester bases and treated with $50 \mathrm{w} / \mathrm{w} \%$ aqueous hydroxylamine solution and produced enantiomerically enriched hydroxamic acids. Hydroxamic acid enantiomers $(+)-80$ and $(-)-80$ were prepared from enantiomers of diendo-3-amino- $N$-hydroxybicyclo[2.2.1]hept-5-ene carboxamide (+)-79 and (-)-79 by catalytic $(\mathrm{Pd} / \mathrm{C})$ hydrogenation in Winci autoclave at $60{ }^{\circ} \mathrm{C}$ under 50 bar pressure.

We also studied the reactivity and selectivity of the domino ring-closure reaction of alicyclic hydroxamic acid with oxocarboxylic acids to form new isoindolo[2,1a]quinazolines and methanopyrrolo[1,2-a]quinazolines, diendo- and diexo-3-amino- $N$ hydroxybicyclo[2.2.1]hept-5-ene-carboxamide derivatives. Of the products, $( \pm)$-79 and $( \pm)$ 81 were chosen as model compounds. The reactions were first carried out with racemic compounds then extended to enantiomeric hydroxamic acids as well.

2-Formylbenzoic acid or 6-formyl-2,3-dimethoxybenzoic acid along with diendohydroxamic acid $( \pm)$-79 and diexo-hydroxamic acid $( \pm)-81$ were heated at reflux in a 
mixture of EtOH and toluene in the presence of $p$-TsA for $8 \mathrm{~h}$. Alternatively, the reaction mixture was stirred at $100{ }^{\circ} \mathrm{C}$ for 30 min under microwave irradiation (max. $300 \mathrm{~W}$ ). In all cases, the ${ }^{1} \mathrm{H}$ NMR spectra revealed the formation of the single epimers of isoindolo[2,1a] quinazoline $( \pm)-88-( \pm)-91$.

The ring-closure reaction with levulinic acid and $\alpha$-ketoglutaric acid, under similar conditions, resulted in two epimers of methanopyrrolo[1,2-a]quinazolines $( \pm)-92-( \pm)-95$. Epimers of $( \pm)-92-( \pm)-95$ were not separable, but after reaction with diazomethane, the epimeric methoxy derivatives of $( \pm)-96 \mathbf{a}-( \pm)-99 \mathbf{a}$ and $( \pm)-96 \mathbf{b}-( \pm)-99 \mathbf{b}$ could be easily separated by column chromatography eluting with EtOAc. The stereoselectivity of the domino ring-closures was detected by ${ }^{1} \mathrm{H}-\mathrm{NMR}$ spectroscopy. Relative configurations of the newly-built stereogenic centres of $( \pm)-\mathbf{8 8}-( \pm)-91$ and $( \pm)-96 \mathbf{a},( \pm)-97 \mathbf{a},( \pm)-99 b$ were successfully elucidated via X-rays crystallography or 2D-NMR spectroscopy (depending on the characteristic NOE crosspeaks). It can be concluded that the high rigidity of the norbornene skeleton facilitates the efficient transfer of the stereochemical information to the newly-formed stereogenic centre of the isoindolo- and methanopyrrolo-quinazolinones.

Various conditions for the retro Diels-Alder reaction of domino products $( \pm)$-88$( \pm)$-95 were applied such as heating the molten phase or treatment under microwave irradiation in various solvents (toluene, DMF, dioxane, or DCB), but conversions were not complete.

In order to obtain more hydrophobic compounds, $O$-methyl $( \pm)-\mathbf{1 0 3},( \pm)-\mathbf{1 0 4},( \pm)-$ 107 and $( \pm)-108$ as well as $O$-benzyl $( \pm)$-105, $( \pm)$-106, $( \pm)$-109 and $( \pm)$-110 derivatives were successfully synthesized from isoindolo[2,1-a]quinazolinones ( \pm )-88-( $( \pm)-\mathbf{9 1}$.

Cycloreversions of the synthesized $O$-methyl and $O$-benzyl derivatives were accomplished in several conditions including heating in the molten phase, thermal and microwave treatment in various solvents (toluene, DMF, dioxane, DCB). Finally, heating by microwave irradiation in DCB was found to the most efficient. The crude products were purified by column chromatography to provide pyrimido[2,1- $a$ ]isoindoles $( \pm)-\mathbf{1 1 1}-( \pm)-114$ and pyrrolo[1,2-a]pyrimidines $( \pm)-\mathbf{1 1 5},( \pm)$-116 as white crystals after evaporation or crystallisation from $i \operatorname{Pr}_{2} \mathrm{O}$.

When enantiomeric hydroxamic acids (+)-79 and (+)-81 were used in the dominoRDA protocol, the final products pyrimido[2,1-a]isoindole (-)-111, (+)-111, (-)-112, (+)112, (-)-113, (+)-113, (-)-114 and (+)-114 and pyrrolo[1,2-a]pyrimidine (-)-115, (+)-115, $(-)-116$ and (+)-116 derivatives were enantiomeric heterocycles with $e e=93-99 \%$, demonstrating that the starting hydroxamic acids are excellent chiral sources. It is 
demonstrable, that the stereochemical information was transferred efficiently to the newlyformed stereogenic centre through a traceless chirality transfer strategy. The configuration remains constant during the RDA reaction, which allowed to define the absolute configuration of the final products. Simplicity, short reaction time, good yield, mild experimental conditions and easy work-up are the main advantages of our protocol. 


\section{ACKNOWLEDGMENTS}

I am greatly indebted to my supervisor

\section{Professor Ferenc Fülöp}

Head of the Institute of Pharmaceutical Chemistry,

for providing me the opportunity to perform my work at the Institute. I am grateful for his scientific guidance, his inspiring ideas and his constructive criticism.

I would like to express my warmest thanks to

\section{Dr. Márta Palkó.}

Her useful advice, stimulating suggestions and encouragement have helped me throughout the time of my PhD work.

I am grateful to all members of the Institute of Pharmaceutical Chemistry,

for their help and friendship.

I feel very fortunate to have been able to work in such a collaborative

environment.

Finally, I would like to give my special thanks to my family for their love and support during my $\mathrm{PhD}$ studies. 


\section{TABLE OF THE SYNTHESIZED COMPOUNDS}

\begin{tabular}{|c|c|}
\hline $\begin{array}{c}\text { Compound } \\
\text { number in the } \\
\text { thesis }\end{array}$ & $\begin{array}{l}\text { Article number/ } \\
\text { Compound number } \\
\text { in the article }\end{array}$ \\
\hline$( \pm)-72$ & $\mathbf{I} /( \pm)-1$ \\
\hline$(+)-72$ & $\mathrm{I} /(+)-1$ \\
\hline$(-)-72$ & $\mathrm{I} /(-)-1$ \\
\hline$( \pm)-73$ & $I /( \pm)-4$ \\
\hline$(+)-73$ & $\mathrm{I} /(+)-4$ \\
\hline$(-)-73$ & $I /(-)-4$ \\
\hline$(-)-75$ & IV/4A \\
\hline$(+)-76$ & IV/2A \\
\hline$(-)-77$ & IV/4C \\
\hline$(+)-78$ & IV/2C \\
\hline$(+)-79$ & $\mathrm{I} /(+)-2$ \\
\hline$(-)-79$ & $I /(-)-2$ \\
\hline$(+)-80$ & III/4A \\
\hline$(-)-80$ & III/4B \\
\hline$(+)-81$ & $I /(+)-5$ \\
\hline$(-)-81$ & $I /(-)-5$ \\
\hline$(+)-82$ & III/3A \\
\hline$(-)-82$ & III/3B \\
\hline$(-)-87$ & $I /(-)-3$ \\
\hline$(-)-88$ & $I /(-)-6$ \\
\hline$(+)-89$ & $I /(+)-16$ \\
\hline$(-)-90$ & $\mathrm{I} /(-)-7$ \\
\hline$(+)-91$ & $\mathrm{I} /(+)-17$ \\
\hline$(+)-96 a$ & II $/(+)-6 a$ \\
\hline$(-)-96 b$ & II/(-)-6b \\
\hline
\end{tabular}

\begin{tabular}{|c|c|}
\hline$(-)-97 a$ & II/(-)-7b \\
\hline$(+)-97 b$ & $\mathbf{I I} /(+)-7 \mathbf{a}$ \\
\hline$(-)-98 \mathbf{a}$ & $\mathbf{I I} /(-)-\mathbf{3 a}$ \\
\hline$(+)-98 b$ & $I I /(+)-3 b$ \\
\hline$(-)-99 a$ & II/(-)-4a \\
\hline$(+)-99 b$ & $I I /(+)-4 b$ \\
\hline$(-)-103$ & $I /(-)-8$ \\
\hline$(-)-104$ & $I /(-)-9$ \\
\hline$(+)-105$ & $I /(+)-10$ \\
\hline$(+)-106$ & $\mathrm{I} /(+)-11$ \\
\hline$(+)-107$ & $I /(+)-18$ \\
\hline$(+)-108$ & $\mathrm{I} /(+)-19$ \\
\hline$(-)-109$ & $I /(-)-20$ \\
\hline$(-)-110$ & $I /(-)-21$ \\
\hline$(+)-111$ & $I /(+)-12$ \\
\hline$(-)-111$ & $I /(-)-12$ \\
\hline$(+)-112$ & $\mathrm{I} /(+)-13$ \\
\hline$(-)-112$ & $I /(-)-13$ \\
\hline$(+)-113$ & $I /(+)-14$ \\
\hline$(-)-113$ & $I /(-)-14$ \\
\hline$(+)-114$ & $\mathrm{I} /(+)-15$ \\
\hline$(-)-114$ & $I /(-)-15$ \\
\hline$(+)-115$ & II $/(+)-5$ \\
\hline$(-)-115$ & II $/(-)-5$ \\
\hline$(+)-116$ & II $/(+)-8$ \\
\hline$(-)-116$ & II $/(-)-8$ \\
\hline
\end{tabular}




\section{REFERENCES}

[1] H. Lossen, Justus Liebigs Ann. Chem. 1869, 150, 314-322.

[2] H. Ohigashi, M. Kaji, M. Sakaki, K. Koshimizu, Phytochemistry 1989, 28, 1365-1368.

[3] B. R. Wilson, A. R. Bogdan, M. Miyazawa, K. Hashimoto, Y. Tsuji, Trends Mol. Med. 2016, 22, 1077-1090.

[4] J. C. Renshaw, G. D. Robson, A. P. J. Trinci, M. G. Wiebe, F. R. Livens, D. Collison, R. J. Taylor, Mycol. Res. 2002, 106, 1123-1142.

[5] B. Cooper, H. F. Bunn, R. D. Propper, D. G. Nathan, D. S. Rosenthal, W. C. Moloney, Am. J. Med. 1977, 63, 958-966.

[6] A. K. Gupta, T. Plott, Int. J. Dermatol. 2004, 43, 3-8.

[7] B. S. Mann, J. R. Johnson, K. He, R. Sridhara, S. Abraham, B. P. Booth, L. Verbois, D. E. Morse, J. M. Jee, S. Pope, R. S. Harapanhalli, R. Dagher, A. Farrell, R. Justice, R. Pazdur, Clin. Cancer Res. 2007, 13, 2318-2322.

[8] D. C. Bhura, S. G. Tandon, Anal. Chim. Acta 1971, 53, 379-386.

[9] a., Z. Li, H. Yamamoto, Acc. Chem. Res. 2013, 46, 506-518; b., K. Ahlford, H. Adolfsson, Catal. Commun. 2011, 12, 1118-1121; c., A. U. Barlan, W. Zhang, H. Yamamoto, Tetrahedron 2007, 63, 6075-6087; d., K. J. Xiao, D. W. Lin, M. Miura, R. Y. Zhu, W. Gong, M. Wasa, J. Q. Yu, J. Am. Chem. Soc. 2014, 136, 8138-8142.

[10] C. J. Marmion, J. P. Parker, K. B. Nolan, Compr. Inorg. Chem. II, 3, Elsevier B.V., 2013, pp. 683-708.

[11] T. Kolasa, Tetrahedron 1983, 39, 1753-1754.

[12] R. Codd, Coord. Chem. Rev. 2008, 252, 1387-1408.

[13] Z. Rappoport, J. F. Liebman, Editors, The Chemistry of Hydroxylamines, Oximes and Hydroxamic Acids, Part 1, John Wiley \& Sons Ltd., 2009. pp 29-50.

[14] T. Bugg, ChemBioChem 2014, 15, 2467-2470.

[15] B. Kurzak, E. Farkas, T. Glowiak, H. Kozlowski, J. Chem. Soc., Dalton Trans. 1991, 163-167. 
[16] Y. Samuni, U. Samuni, S. Goldstein, Biochim. Biophys Acta, Gen. Subj. 2012, 1820, 1560-1566.

[17] M. R. Yadav, P. R. Murumkar, V. P. Zambre, Matrix Metalloproteinase inhibitors, Springer, Basel 2012, 103, pp 83-135.

[18] E. M. F. Muri, M. J. Nieto, R. D. Sindelar, J. S. Williamson, Curr. Med. Chem. 2002, 9, 1631-1653.

[19] a., J. E. Bolden, M. J. Peart, R. W. Johnstone, Nat. Rev. Drug Discovery 2006, 5, 769-784; b., D. Pal, S. Saha, J. Adv. Pharm. Technol. Res. 2012, 3, 92-99; c., A. Aparicio, Clin. Lung Cancer 2006, 7, 309-312.

[20] I. Mutule, D. Borovika, E. Rozenberga, N. Romanchikova, R. Zalubovskis, I. Shestakova, P. Trapencieris, J. Enzyme Inhib. Med. Chem. 2015, 30, 216-223.

[21] R. Codd, N. Braich, J. Liu, C. Z. Soe, A. A. H. Pakchung, Int. J. Biochem. Cell Biol. 2009, 41, 736-739.

[22] P. Atadja, Cancer Lett. 2009, 280, 233-241.

[23] C. Wu, P. A. Miller, M. J. Miller, Bioorg. Med. Chem. Lett. 2011, 21, 26112615.

[24] B. Chetan, M. Bunha, M. Jagrat, B. N. Sinha, P. Saiko, G. Graser, T. Szekeres, G. Raman, P. Rajendran, D. Moorthy, A. Basu, V. Jayaprakash, Bioorg. Med. Chem. Lett. 2010, 20, 3906-3910.

[25] a., R. De Vreese, M. D'Hooghe, Eur. J. Med. Chem. 2017, 135, 174-195; b., F. Thaler, M. Varasi, A. Abate, G. Carenzi, A. Colombo, C. Bigogno, R. Boggio, R. Dal Zuffo, D. Rapetti, A. Resconi, N. Regalia, S. Vultaggio, G. Dondio, S. Gagliardi, S. Minucci, C. Mercurio, Eur. J. Med. Chem. 2013, 64, 273-284.

[26] S. DasGupta, P. R. Murumkar, R. Giridhar, M. R. Yadav, Bioorg. Med. Chem. 2009, 17, 444-459.

[27] P. Vassalli, Annu. Rev. Immunol. 1992, 10, 411-452.

[28] a., X. Cheng, Y. Shen, R. Li, Drug Discovery Today 2014, 19, 1822-1827; b., L. Yang, K. Lindholm, Y. Konishi, R. Li, Y. Shen, J. Neurosci. 2002, 22, 30253032 .

[29] B. Barlaam, T. G. Bird, C. Lambert-van der Brempt, D. Campbell, S. J. Foster, R. Maciewicz, J. Med. Chem. 1999, 42, 4890-4908. 
[30] C.-B. Xue, M. E. Voss, D. J. Nelson, J. J. W. Duan, R. J. Cherney, I. C. Jacobson, X. He, J. Roderick, L. Chen, R. L. Corbett, L. Wang, D. T. Meyer, K. Kennedy, W. F. DeGrado, K. D. Hardman, C. A. Teleha, B. D. Jaffee, R.-Q. Liu, R. A. Copeland, M. B. Covington, D. D. Christ, J. M. Trzaskos, R. C. Newton, R. L. Magolda, R. R. Wexler, C. P. Decicco, J. Med. Chem. 2001, 44, 2636-2660.

[31] J. J. W. Duan, L. Chen, Z. R. Wasserman, Z. Lu, R.-Q. Liu, M. B. Covington, M. Qian, K. D. Hardman, R. L. Magolda, R. C. Newton, D. D. Christ, R. R. Wexler, C. P. Decicco, J. Med. Chem. 2002, 45, 4954-4957.

[32] R. J. Cherney, J. J. W. Duan, M. E. Voss, L. Chen, L. Wang, D. T. Meyer, Z. R. Wasserman, K. D. Hardman, R.-Q. Liu, M. B. Covington, M. Qian, S. Mandlekar, D. D. Christ, J. M. Trzaskos, R. C. Newton, R. L. Magolda, R. R. Wexler, C. P. Decicco, J. Med. Chem. 2003, 46, 1811-1823.

[33] G. R. Ott, N. Asakawa, Z. Lu, R.-Q. Liu, M. B. Covington, K. Vaddi, M. Qian, R. C. Newton, D. D. Christ, J. M. Traskos, C. P. Decicco, J. J. W. Duan, Bioorg. Med. Chem. Lett. 2008, 18, 694-699.

[34] a., A. Di Fiore, A. Maresca, C. T. Supuran, G. De Simone, Chem. Commun. 2012, 48, 8838-8840; b., S. P. Gupta, V. Maheswaran, V. Pande, D. Kumar, J. Enzyme Inhib. Med. Chem. 2003, 18, 7-13.

[35] B. Jiang, X. J. Huang, H. Q. Yao, J. Y. Jiang, X. M. Wu, S. Y. Jiang, Q. J. Wang, T. Lu, J. Y. Xu, Org. Biomol. Chem. 2014, 12, 2114-2127.

[36] I. A. Butovich, S. M. Lukyanova, J. Lipid Res. 2008, 49, 1284-1294.

[37] L. Goodman, T. B. Coles, S. Budsberg, J. Vet. Pharmacol. Ther. 2008, 31, 387398.

[38] J. H. Hogg, I. R. Ollmann, J. Z. Haeggstroem, A. Wetterholm, B. Samuelsson, C.-H. Wong, Bioorg. Med. Chem. 1995, 3, 1405-1415.

[39] a., H. Maehr, Pure Appl. Chem. 1971, 28, 603-636; b., S. P. Gupta, Chem. Rev. 2015, 115, 6427-6490.

[40] S. Pepeljnjak, B. Zorc, I. Butula, Acta Pharm. (Zagreb, Croatia) 2005, 55, 401408.

[41] R. A. Burne, Y.-Y. M. Chen, Microbes Infect. 2000, 2, 533-542. 
[42] S. Odake, T. Morikawa, M. Tsuchiya, L. Imamura, K. Kobashi, Biol. Pharm. Bull. 1994, 17, 1329-1332.

[43] Z.-P. Xiao, Z.-Y. Peng, J.-J. Dong, R.-C. Deng, X.-D. Wang, H. Ouyang, P. Yang, J. He, Y.-F. Wang, M. Zhu, X.-C. Peng, W.-X. Peng, H.-L. Zhu, Eur. J. Med. Chem. 2013, 68, 212-221.

[44] T. G. Barros, J. S. Williamson, O. A. C. Antunes, E. M. F. Muri, Lett. Drug Des. Discovery 2009, 6, 186-192.

[45] K. Aubart, M. Zalacain, Prog. Med. Chem. 2006, 44, 109-143.

[46] C. Apfel, D. W. Banner, D. Bur, M. Dietz, T. Hirata, C. Hubschwerlen, H. Locher, M. G. P. Page, W. Pirson, G. Rosse, J.-L. Specklin, J. Med. Chem. 2000, 43, 2324-2331.

[47] V. Molteni, X. He, J. Nabakka, K. Yang, A. Kreusch, P. Gordon, B. Bursulaya, I. Warner, T. Shin, T. Biorac, N. S. Ryder, R. Goldberg, J. Doughty, Y. He, Bioorg. Med. Chem. Lett. 2004, 14, 1477-1481.

[48] a., A. Porcheddu, G. Giacomelli, J. Org. Chem. 2006, 71, 7057-7059. b., A. Angeli, Gazz. Chim. Ital. 1896, 26, 17-28. c., E. Rimini, Gazz. Chim. Ital. 1901, 31, 84-98. d., G. Dettori, S. Gaspa, A. Porcheddu, L. De Luca, Adv. Synth. Catal., 2014, 356, 2709-2713.

[49] L. De Luca, G. Giacomelli, M. Taddei, J. Org. Chem. 2001, 66, 2534-2537.

[50] A. Massaro, A. Mordini, G. Reginato, F. Russo, M. Taddei, Synthesis 2007, 3201-3204.

[51] A. S. Reddy, M. S. Kumar, G. R. Reddy, Tetrahedron Lett. 2000, 41, 62856288.

[52] G. R. Vasanthakumar, V. V. S. Babu, Tetrahedron Lett. 2003, 44, 4099-4101.

[53] M. A. Bailén, R. Chinchilla, D. J. Dodsworth, C. Nájera, Tetrahedron Lett. 2001, 42, 5013-5016.

[54] K. Yang, B. Lou, Mini-Rev. Med. Chem. 2003, 3, 349-360.

[55] G. Giacomelli, A. Porcheddu, M. Salaris, Org. Lett. 2003, 5, 2715-2717.

[56] J. M. Altenburger, C. Mioskowski, H. d'Orchymont, D. Schirlin, C. Schalk, C. Tarnus, Tetrahedron Lett. 1992, 33, 5055-5058. 
[57] T. Ezawa, Y. Kawashima, T. Noguchi, S. Jung, N. Imai, Tetrahedron: Asymmetry 2017, 28, 1690-1699.

[58] E. E. Smissman, V. D. Warner, J. Med. Chem. 1972, 15, 681-682.

[59] M. Löppenberg, H. Muller, C. Pulina, A. Oddo, M. Teese, J. Jose, R. Holl, Org. Biomol. Chem. 2013, 11, 6056-6070.

[60] A. Kirschning, W. Solodenko, K. Mennecke, Chem. Eur. J. 2006, 12, 59725990.

[61] M. Devocelle, B. M. McLoughlin, C. T. Sharkey, D. J. Fitzgerald, K. B. Nolan, Org. Biomol. Chem. 2003, 850-853.

[62] L. R. Lampariello, D. Piras, M. Rodriquez, M. Taddei, J. Org. Chem. 2003, 68, 7893-7895.

[63] E. Riva, S. Gagliardi, C. Mazzoni, D. Passarella, A. Rencurosi, D. Vigo, M. Martinelli, J. Org. Chem. 2009, 74, 3540-3543.

[64] T. Kurz, M. K. Pein, L. Marek, C. T. Behrendt, L. Spanier, K. Kuna, K. Büchner, Eur. J. Org. Chem. 2009, 18, 2939-2942.

[65] J. Lee, A. J. Chubb, E. Moma, B. M. Mcloughlin, C. T., Sharkey, J. G. Kelly, K. B. Nolan, M. Devocelle, D. J. Fitzgerald, Org. Biomol. Chem. 2005, 3, 36783685.

[66] a., D. Griffith, K. Krot, J. Comiskey, K. B. Nolan, C. J. Marmion, J. Chem. Soc. Dalton Trans. 2008, 1, 137-147., b., J. Shpernat, M. Mizhiritskii, 2005, PCT Int. Appl. WO 2005007634 A1 20050127., c., W. M. Shi, X.-P. Ma, C. X. Pan, G.F. Su, D.L. Mo, J. Org. Chem. 2015, 80, 11175-11183. d., M. A. Stolberg, N. A. Mosher, T. Wagner-Jauregg, J. Am. Chem. Soc. 1957, 79, 2615-2617., e., Z. Eckstein, T. Jadach, E. Lipcynska-Kochani, J. Chem. Eng. Data 1983, 28, 272281., f., M. Ahmed, S. Nencatti, M. R. Mazzoi, F. Porchia, F. Antonelli, A. Lapucci, Med. Chem. 2008, 4, 298-308.

[67] J. Valgeirsson, E. O. Nielsen, P. Peter, PCT Int. Appl. 2004, WO 2004046090 A2 20040603

[68] P. Tardibono, M. J. Miller, Org. Lett. 2009, 11, 1575-1578.

[69] A. El-Faham, F. Albericio, Eur. J. Org. Chem. 2009, 1499-1501

[70] F. A. Davis, N. Theddu, J. Org. Chem. 2010, 75, 3814-3820. 
[71] L. A. Shemchuk, V. P. Chernykh, O. S. Krys'kiv, Russ. J. Org. Chem. 2006, 42, 382-387.

[72] J. L. Romine, S. W. Martin, N. A. Meanwell, J. R. Epperson, Synthesis 1994, 846-850.

[73] R. Cheng, T. Guo, D. Zhang-Negrerie, Y. Du, K. Zhao, Synthesis 2013, 45, 2998-3006.

[74] K. Tanaka, K. Matsuo, A. Nakanishi, Y. Kataoka, K. Takase, S. Otsuki, Chem. Pharm. Bull. 1988, 36, 2323-2330.

[75] a., I. Berner, P. Yakirevitch, J. Libman, A. Shanzer, G. Winkelmann, Biol. Met. 1991, 4, 186-191; b., J. Besserglick, E. Olshvang, A. Szebesczyk, J. Englander, D. Levinson, Y. Hadar, E. Gumienna-Kontecka, A. Shanzer, Chem. Eur. J. 2017, 23, 13181-13191; c., T. Richardson-Sanchez, W. Tieu, M. P. Gotsbacher, T. J. Telfer, R. Codd, Org. Biomol. Chem. 2017, 5719-5730.

[76] a., S. Albrecht, A. Defoin, E. Salomon, C. Tarnus, A. Wetterholm, J. Z. Haeggstroem, Bioorg. Med. Chem. 2006, 14, 7241-7257; b., D. Borovika, P. Bertrand, P. Trapencieris, Chem. Heterocycl. Comp. 2014, 49, 1560-1578.

[77] a., E. Forró, F. Fülöp Tetrahedron: Asymmetry, 2004, 15, 2875-2880. b., R. T. Stendall, A. J. A. Cobb Tetrahedron, 2018, 74, 4917-4925. c., Z. Wang, Z. Hou, S. Yao, M. Lin, H. Song Anal. Chim. Acta, 2017, 960, 81-89. d., A. Giuffrida, G. Maccarone, V. Cucinotta, S. Orlandini, A. Contino, J. Chromatogr. A, 2014, $1363,41-50$.

e.,J. D. Clark, B. Han, A. S. Bhown, S. R. Wickramasinghe Sep. Purif. Technol., 2005, 42, 201-211.

[78] M. Palkó, M. M. Hänninen, R. Sillanpää, F. Fülöp Molecules, 2013, 18, 1508015093.

[79] F. Faigl, E. Fogassy, M. Nógrádi, E. Pálovics, J. Schindler Tetrahedron: Asymmetry, 2008, 19, 519-536.

[80] R. Siedlecka, Tetrahedron 2013, 69, 6331-6363.

[81] F. Fülöp, M. Palkó, E. Forró, M. Dervarics, T. A. Martinek, R. Sillanpää, Eur. J. Org. Chem. 2005, 3214-3220.

[82] L. Kiss, E. Forró, F. Fülöp, Tetrahedron Lett. 2006, 47, 2855-2858. 
[83] D. Xu, K. Prasad, O. Repič, T. J. Blacklock, Tetrahedron: Asymmetry 1997, 8, 1445-1451.

[84] C. Cimarelli, G. Palmieri, J. Org. Chem. 1996, 61, 5557-5563.

[85] L. T. Kanerva, P. Csomós, O. Sundholm, G. Bernáth, F. Fülöp, Tetrahedron: Asymmetry 1996, 7, 1705-1716

[86] L. Kiss, M. Cherepanova, E. Forró, F. Fülöp, Chem. Eur. J. 2013, 19, 21022107.

[87] a., G. Stájer, E. A. Szabó, F. Fülöp, G. Bernáth, P. Sohár, J. Heterocycl. Chem. 1983, 20, 1181-1185. b., P. Sohár, F. Miklós, A. Csámpai, G. Stájer, J. Chem. Soc., Perkin Trans. 1 2001, 558-564.

[88] a., F. Miklós, Z. Tóth, M. M. Hänninen, R. Sillanpää, E. Forró, F. Fülöp, Eur. J. Org. Chem. 2013, 4887-4894; b., F. Fülöp, F. Miklós, E. Forró, Synlett 2008, 1687-1689; c., F. Miklós, K. Bozó, Z. Galla, M. Haukka, F. Fülöp, Tetrahedron: Asymmetry 2017, 28, 1401-1406.

[89] M. Elyashberg, Trends Anal. Chem. 2015, 69, 88-97. 
ANNEX 